\title{
Umbilical Cord Blood Hematopoietic Stem Cell Transplantation, an Alternative to Bone Marrow
}

\author{
Mortada Salman Najem (Corresponding author) \\ Department of Biology and Biotechnology, Worcester Polytechnic Institute \\ 100 Institute Road, Worcester, MA01609, USA \\ E-mail: Mortada.najem@wpi.edu \\ Kyaw Thu Minn \\ Department of Biomedical Engineering, Worcester Polytechnic Institute \\ 100 Institute Road, Worcester, MA01609, USA \\ E-mail: Kyawthuminn@wpi.edu
}

Received: March 21, 2011 Accepted: April 2, 2011 doi:10.5539/gjhs.v3n2p10

\begin{abstract}
Umbilical cord blood (UCB) is an alternative hematopoietic stem cell (HSC) source. It is widely applicable for ameliorating several diseases through HSC transplants. One of the few disadvantages of this source of stem cells is the limited amount of HSCs that can be extracted from each cord blood unit (CBU).Single CBU transplantation seems to be more ideal in lower weight, younger patients. Adult clinical studies comparing HSCs from a single CBU and HSCs from bone marrow indicate that umbilical cord blood transplantation is a viable method when a matched bone marrow transplant cannot be identified. Further clinical studies using two CBUs suggest better engraftment and lower risk of relapse. However, double cord blood transplantation has been faced with the challenge of single unit dominance in most studies. Ex vivo expansion of UCB HSC is another promising method to overcome limited HSC counts.
\end{abstract}

Keywords: Umbilical cord blood, Hematopoietic stem cells, Umbilical cord blood transplantation, Double cord blood transplantation, Ex Vivo expansion

\section{Introduction}

Originally thrown away after the delivery of the baby, umbilical cord blood (UCB) was first considered as a source of stem cells in the 1970s (Mayani, Alvarado-Moreno \& Flores-Guzmán, 2003). Recent advances in the potential of UCB have revealed therapeutic uses of HSCs (Eapen et al., 2007; Gluckman et al., 1989; Rocha et al., 2001). The presence of hematopoietic progenitor cells in human UCB was first evidenced by Knudtzon in 1974 (Knudtzon, 1974). Approximately 10 years later, the presence of more primitive hematopoietic progenitor cells was observed by Leary and Ogawa(Leary \& Ogawa, 1987).UCB has the potential to be used as a therapeutic tool due to its abilities to engraft (Broxmeyer et al., 1989). In comparison to bone marrow (BM) hematopoietic stem cells (HSCs), UCB is easier to attain, more available, and requires less compatibility with the patient.

UCB has been a successful alternative to BM as a source of HSCs for treating a variety of hematologic disorders and malignant/non-malignant diseases such as leukemia, lymphoma, and sickle cell anemia (Broxmeyer, 2010; Higuchi et al., 2010). UCB was first tested on a young boy who had Fanconi Anemia, an autosomal recessive disorder. Fanconi Anemia is characterized by hematological abnormalities and BM failure. The transplant of UCB from a female HLA-identical sibling allowed the boy to regenerate all hematopoietic efficacies that were limited by the disease (Gluckman et al., 1989). This success has been a vital motivation to all subsequent research on UCB. The first unrelated umbilical cord blood transplant (UCBT) was performed in 1993 on patients with malignant and non-malignant diseases (Kurtzberg et al., 1996). In 1996, Laporte et al reported successful UCBT in an adult with chronic myelogenic leukemia from an unrelated donor (Laporte et al., 1996). This innovative use of stem cells has led to a wide increase of UCB banking. As a result, expecting mothers are now more likely to bank their newborn's UCB in cord blood banks (CIBMTR) (Pasquini \& Wang, 2010). 
Here, we provide a review of the most recent research performed on UCBTs. We first examine the essential constituents of UCB including HSCs and mesenchymal stem cells (MSCs). We further review the advantages and disadvantages of UCBT HSCs as opposed to bone marrow transplant (BMT) HSCs by examining clinical trials. Since there are less HSCs in UCB than in BM, we discuss methods that overcome the limitation of HSCs from a single cord through double cord blood transplantation (DCBT) and ex-vivo expansion. Additionally, we analyze clinical studies performed on DCBT which use various types of conditioning regimens including reduced intensity conditioning (RIC), myeloablative conditioning (MAC), and non-myeloablative conditioning (NMAC). Lastly, we discuss the processes of UCB extraction, cryopreservation and banking.

\section{Essential constituents of Umbilical Cord Blood}

The umbilical cord (UC) is the basic life-line support for all newborns. It is the essential tube in which all nutrients and nourishments are transported from the mother to the embryo. Following delivery, the umbilical cord is usually clamped and discarded. The human umbilical cord begins to form in the first 5 weeks of pregnancy. The allantois, a membrane formed out of the gut, contains umbilical vessels that attach the fetus to the developing placenta. Blood vessels typically develop from the yolk sac, which will then combine with the umbilical vessels. The amnion or the membrane surrounding the amniotic fluid envelops the allantois and the yolk sac, forming the developing umbilical cord. In the following months leading up to birth, the umbilical cord begins to insert deeper into the abdomen of the fetus (Kurt Benirschke \& Peter Kaufmann, 2000). The umbilical cord consists of two arteries and one vein arranged in a helical structure (Figure 1). The two arteries of the umbilical cord spiral around the umbilical vein, making them stiffer and more difficult to rupture. Opposite to the arteries and veins of the human heart (except for the pulmonary arteries), umbilical cord arteries and veins carry deoxygenated blood to the placenta and oxygenated blood from the placenta to the developing fetus, respectively. The three vessels of the umbilical cord are embedded in a connective tissue gelatinous base known as the Wharton's Jelly which insulates the umbilical cord.

A striking difference between the umbilical arteries and vein is observed in the endothelial cells at 10 weeks gestation. The endothelial cells of the arteries become richer in glycogen (Parry \& Abramovich, 1972). At 15 weeks gestation, venous endothelium contains the most amount of rough endoplasmic reticulum and thereafter decreases until almost none is seen by mid-pregnancy. Arterial endothelium contained rough endoplasmic reticulum that progressively increased over the course of the pregnancy.

\subsection{Hematopoietic Stem Cells}

HSCs are multipotent and have the capability to self-renew and differentiate into all mature blood cells including myeloids such as granulocytes, monocytes, leukocytes, erythrocytes, and megakaryocytes, and lymphoids such as T-lymphocytes and B-lymphocytes (Figure 2) (Gunsilius, Gastl, \& Petzer, 2001; Higuchi et al., 2010). HSCs in UCB are similar to those in BM and peripheral blood in their capacity for differentiation. They can self-renew and they contain erythroid and granulocyte-macrophage progenitor cells when examined in an in vitro colony assay (Broxmeyer et al., 1989).

Current scientific investigation is attempting to determine the best marker for HSCs. The most recent significant constituents of UCB are erythrocytes, endothelial cells, MSCs, HSCs, and Tregs. Many other mononuclear cells are found in UCB, making it difficult to identify HSCs. A common marker used is cell determinant-34 (CD34), a glycoprotein found on the surface of the HSCs and progenitor cells that is important for adhesion with neighboring cells (Soiffer, 2008). Simple combinations of markers that efficiently select for HSCs have not yet been determined. Protocols experimenting with complex combinations of markers have provided a more efficient method of detecting these stem cells. One such protocol begins by reducing the amounts of cells that portray any lineage-specific markers and then using the remaining cells to positively select for Sca- $1^{+}$Lineage-c-kit ${ }^{+}$cells (Osawa, Hanada, Hamada, \& Nakauchi, 1996). However, this protocol only gives20\% multilineage reconstitution (Morrison, Hemmati, Wandycz, \& Weissman, 1995; Osawa et al., 1996; Spangrude, Brooks, \& Tumas, 1995; Wagers, Sherwood, Christensen, \& Weissman, 2002). More recently, a protocol using the signaling lymphocyte activation molecule family of markers were recognized to distinguish between 'true' HSCs and primitive progenitor cells. Microarray analysis was performed on three markers from the signaling lymphocyte activation molecule family, and the most purified HSCs pertained to $\mathrm{CD} 150^{+} \mathrm{CD} 244^{-} \mathrm{CD} 48^{-}$cells (Kiel et al., 2005).

\subsection{Mesenchymal Stem Cells}

MSC shave multipotential capabilities to self-renew and differentiate into various cellular lineages including adipocytes, osteocytes, chondrocytes, cardiomyocytes, hepatocytes, and nerve cells (Chen, Shao, Xiang, Dong, \& Zhang, 2008; Kang et al., 2006; Kestendjieva et al., 2008; Romanov, Svintsitskaya, \& Smirnov, 2003). Their 
proliferative properties and their ability to migrate to sites of inflammation make MSCs highly desirable for tissue engineering and cell-based therapy (Chen et al., 2008; Romanov et al., 2003).

To date, BM is the most common source of MSCs (Kestendjieva et al., 2008). BM MSCs have certain disadvantages such as the invasive nature of aspirating BM, the drop in cell number (1 MSC in $10^{4}$ nucleated $\mathrm{BM}$ cells at birth to 1 in $2 \times 10^{6}$ at the age of 80 ) and reduction of proliferative potentials with donor's age (Kestendjieva et al., 2008). UCB provides an alternative source of MSCs that possess better proliferative capabilities than BM MSCs (Rodeck \& Whittle, 2009; Wang et al., 2004).

Previous research by Panepucci et al. (Panepucci et al., 2004) and Jeong et al. (Jeong et al., 2005) showed that MSCs from UCB have similar differentiative properties to MSCs from BM. Similarities include abilities to differentiate into adipose tissue, neuronal tissue, bone forming capacity, hepatocyte-like cells, neuroglial-like cells, bone and cartilage (Rodeck \& Whittle, 2009). Moreover, MSCs from UCB show similar cell morphology and immune phenotype to MSCs from BM (Kern, Eichler, Stoeve, Kluter, \& Bieback, 2006; Romanov et al., 2003). However, previous attempts to isolate MSCs from UCB have been unsuccessful or have resulted in low yields (compared to yield rates of 100\% from BM) (Bieback, Kern, Kluter, \& Eichler, 2004; Kern et al., 2006). Recent research has shown that UCB MSCs may be expanded due to their higher proliferation rate and long culture period (Kern et al., 2006).

Similar to HSCs, surface markers used to identify MSCs are not specific to MSCs but also to other cellular lineages (Bieback \& Kluter, 2009; Li, Gollapudi, Patterson, Huang, \& Tuan, 2010; Westwood \& Clements, 2007). Therefore, a combination of expressed and non-expressed markers are used to identify MSCs. Positive MSC markers include CD29, CD44, CD73 (SH-3, SH-4), CD90 (Thy-1), CD105 (SH-2, Endoglin), and CD166 whereas negative markers include CD11, CD14, CD19, CD31, CD34, CD45, and CD79 (Bieback \& Kluter, 2009; Li et al., 2010; Westwood \& Clements, 2007).

\subsubsection{MSCs as immunoregulators}

MSCs are considered to assist in lowering graft-versus-host-disease (GVHD) in UCBT (Ringdén et al., 2006). This may be attributed to the ability of MSCs in reducing T-cell proliferation and cytokine production (Aggarwal \& Pittenger, 2005; Glennie, Soeiro, Dyson, Lam, \& Dazzi, 2005; Maitra et al., 2004). Exact mechanisms of how MSCs perform their immunosuppression remain unknown. It has been suggested that factors such as transforming growth factor- $\beta$, nitric oxide, and interleukin-10 co-function with MSCs to cause immune suppression (Batten et al., 2006; Groh, Maitra, Szekely, \& Koç, 2005; Sato et al., 2007). Further research is required to determine the feasibility of using MSCs along with UCB HSCs to lower GVHD and improve engraftment rates.

\subsection{Regulatory-T cells as immunoregulators}

T-regulatory cells (Tregs) are immune suppressor cells that restrain allogeneic immune responses. Their ability to respond to foreign or self-antigens allows them to maintain the immune system at a homeostasis (Sakaguchi, Yamaguchi, Nomura \& Ono, 2008). Tregs are typically characterized as $\mathrm{CD} 4{ }^{+} \mathrm{CD} 25^{\text {hi }} \mathrm{T}$ cells that express the fork head box transcription factor (Fontenot et al., 2005). Fork head box transcription factor is crucial for T cell activation and in regulating a variety of immune reactions. It is also the most reliable marker for Tregs.

Tregs in UCB may play a crucial role in hematopoietic stem cell transplants (HSCT). Studies on mice administered with allogeneic HSCs have determined that the depletion of Tregs triggers an increased $\mathrm{T}$ cell response to tumors, self-antigens, and pathogens, resulting in increased GVHD in recipients (Anderson et al., 2004; Chen et al., 2007; Cohen, Trenado, Vasey, Klatzmann, \& Salomon, 2002; Taylor, Lees, \& Blazar, 2002). Conversely, the presence of Tregs resulted in fewer cases of GVHD (Taylor et al., 2004; Trenado et al., 2003). Patients who receive BM transplants are at a higher risk of developing GVHD as compared to patients who receive UCBT (Kim \& Broxmeyer, in press). Reasons for such results remain unknown but it is speculated that the lower percentages of GVHD in UCBT recipients may be due to the Tregs present in UCB (Kim \& Broxmeyer, in press). The lack of human clinical trials, mainly due to the complexity of isolating human $\mathrm{T}$ populations, makes it difficult to validate such a speculation.

\section{Hematopoietic Stem Cell Transplantation}

Once a HSC unit has been identified for a patient, he/she must first be administered on a conditioning regimen 5-10 days before the HSC transplant (Carrier \& Ledingham, 2004). Conditioning regimens are chemotherapy only or chemotherapy combined with total body irradiation (TBI) treated to patients undergoing allogeneic HSCTs (Vriesendorp, 2003). The conditioning regimen destroys diseased cells in the patient's body, opens up space in the bone marrow for new cells, and reduces the risk of rejection by suppressing the immune system 
(Bacigalupo et al., 2009; Casper et al., 2004). The intensity of the conditioning regimens given to patients is crucial and may vary according to age or comorbidities (Nakamae et al., 2009). One of the most common conditioning regimens for patients with acute leukemia or high-risk lymphoma is cyclophosphamide combined with total body irradiation (Cy/TBI). TBI is radiation performed to the entire body as opposed to the specific infected area. This therapy aids in suppressing the patient's immune system to allow for reduced rejection of the transplant. Another common type of conditioning regimen includes busulfan and cyclophosphamide $(\mathrm{Bu} / \mathrm{Cy})$ for patients with chronic myelogenous leukemia (CML). Along with the conditioning regimen, the patient receives chemotherapy treatments. Many of these preparatory therapies for transplant are associated with side effects and risk factors that patients must be informed of beforehand.

\subsection{Conditioning regimens}

There are three common categories of conditioning regimens: (1) myeloablative conditioning (MAC), (2) non-myeloablative conditioning (NMAC) and (3) reduce intensity conditioning (RIC).

MAC regimens are associated with irreversible pancytopenia and myeloablation. Such conditioning requires stem cell support (Bacigalupo et al., 2009). MAC is administered to young patients ( $<50$ years of age) without comorbidities due to its high toxicity (Mielcarek \& Storb, 2003). Even in young patients, MAC is associated with high treatment related mortality rates (Kanda et al, in press; Vriesendorp, 2003). Common MAC regimens include either cyclophosphamide $120 \mathrm{mg} / \mathrm{kg}$ and TBI (12 to $14.4 \mathrm{~Gy}$ ) or $16 \mathrm{mg} / \mathrm{kg}$ busulfan (Mielcarek \& Storb, 2003). Such combination of high doses of TBI and/or alkylating agents is so intense that autologous hematologic recovery is disabled and thus hematopoiesis in patients can only be restored by transplanted HSCs (Bacigalupo et al., 2009).

Bacigalupo et al. defined NMAC regimens as those that cause minimal cytopenia and do not require stem cell support (Bacigalupo et al., 2009). NMAC regimens are developed to reduce toxicity in HSCTs. Such reduction in cytotoxicity provides better results in HSCTs with older or medically weak patients (Mielcarek \& Storb, 2003). NMAC is associated with minimally myelosuppressive regimens combined with intensive immune suppression post-transplant to ensure engraftment (Nakamae et al., 2009). NMAC regimens include the use of fludarabine and/or reduced chemotherapy and radiation (Bacigalupo et al., 2009). Fludarabine is important in NMAC due to its ability to reduce high rate of graft rejection (Horwitz \& Chao, 2010). Common NMAC regimens include combinations of busulfan/fludarabine or TBI 200 cGy/fludarabine (Horwitz \& Chao, 2010). In addition, patients are treated with cyclosporine and mycophenolate mofetil as post-graft immunosuppression (Horwitz \& Chao, 2010; Nakamae et al., 2009).

RIC regimens can neither be defined as MAC or NMAC. Compared to MAC, RIC has a minimum TBI or alkylating agent dosage reduction of 30\% (Bacigalupo et al., 2009). It differs from NMAC in that RIC causes prolonged cytopenia and requires stem cell support (Bacigalupo et al., 2009). According to the Center for International Blood and Marrow Transplant Research (CIBMTR) and National Marrow Donor Program, RIC regimens have to meet one or more of the following criteria (Giralt, 2005):

1. $\leq 500$ cGy total-body irradiation,

2. $\leq 9 \mathrm{mg} / \mathrm{kg}$ total busulfan dose,

3. $\leq 140 \mathrm{mg} / \mathrm{m} 2$ total melphalan dose,

4. $\leq 10 \mathrm{mg} / \mathrm{kg}$ total thiotepa dose and

5. Includes a purine analog - fludarabine, cladribine, or pentostatin.

The aim of RIC regimes is to prevent graft rejection and to establish stable donor-derived hematopoiesis while maintaining low rates of non-hematologic toxicity (Giralt, 2005; Satwani, Cooper, Rao, Veys, \& Amrolia, 2008).

The donor HSCs are transplanted after a patient has been placed on a conditioning regimen. The donor HSCs are infused into the patient's bloodstream through a typical central line. The HSCs will travel along the bloodstream throughout the body for several days, after which they begin to dwell into the spaces of the patient's bone marrow. At this point, the HSCs will grow and will begin producing new blood cells after 1-2 weeks. White blood cells will be formed first, then red blood cells, and lastly platelets. The engraftment, or the process by which the patient's body accepts the new HSCs, will follow 1-3 weeks after transplantation.

\section{$3.2 B M$ vs. $U C B$}

UCBTs are currently one of the most common types of transplants in the United States, as evidenced by the increasing number of transplantation centers (Figure 3) (National Marrow Donor Program, 2010b). The outcomes of transplants from 6/6 matched BM vs. unrelated UCB have been compared in various studies (Table 
1) (Laughlin et al., 2004; Rocha et al., 2004; Takahashi et al., 2004).

A study performed by Laughlin et al. included 150 patients with 1 or 2 HLA mismatched CBUs (Laughlin et al., 2004). The study also included 367 patients receiving 6/6 HLA matched bone marrow units and 83 patients receiving 5/6 HLA matched BM units. UCBT patients had a median body weight less than BMT patients (68kg vs. $76 \mathrm{~kg}$ ). UCB patients received ten-fold less total nucleated cells (TNCs) compared to BMT patients $\left(0.22 \times 10^{8}\right.$ vs. $2.4 \times 10^{8}$ per $\mathrm{kg}$ of body weight). The recovery times for neutrophils $\left(>500 \mathrm{cells} / \mathrm{mm}^{3}\right)$ and platelets $(20000$ cells $/ \mathrm{mm}^{3}$ ) were both delayed for UCBT recipients compared to BMT recipients (27 days vs. 18 days, 95\% CI and 60 days vs. 29 days, 95\% CI). Similarly cumulative incidences for neutrophil recovery at 100 days and platelet recovery at one year after matched BM transplants were significantly higher than in UCBT. However, compared to 1-HLA mismatch BMTs, UCBTs resulted in similar cumulative incidences of neutrophil recovery at 100 days $(p=0.29)$ and platelet recovery at one year $(p=0.16)$. The rate of acute II-IV GVHD was similar between matched BMT and UCBT (48\% vs. 41\%, 95\% CI). Patients who survived after 90 days were assessed for chronic GVHD which was higher in UCBT patients than in matched BMT patients (35\% vs. 51\%). However, UCBT patients developed less acute II-IV GVHD occurrences than mismatched BMT patients (95\% CI) while chronic GVHD rates were similar. TRM was significantly higher in UCBT patients than in matched BMT patients (63\% vs. $46 \%$ ). Treatment failures developed in $69 \%$ of matched BMTs and $81 \%$ of UCBTs. Leukemia relapse was observed in 26 out of 150 UCBT patients and 83 out of 367 BMT patients. The DFS rate after 3 years was $23 \%$ and $33 \%$ for UCBT and BMT patients, respectively. After 100 days, the rates of death in UCBT patients were significantly higher than in matched BMT patients $(70 \%$ vs. $50 \%, p<0.001)$. The proportion of deaths due to infection was higher in UCBT patients than in both matched and mismatched BMT patients. Although TRM, rate of treatment failure, and overall mortality were significantly higher in UCBT patients than in matched BMT patients, the rates were similar with BMTs that have 1 HLA mismatch.

A four-year retrospective study by Rocha et al. compared 98 UCBTs and 584 BMTs in patients diagnosed with acute leukemia (Rocha et al., 2004). UCBT patients were diagnosed with more advanced leukemia at the time of transplantation $(p<0.001)$. The median age and body weight of UCBT patients were both less than BMT patients (24.5 years and $58 \mathrm{~kg}$ vs. 32 years and $68 \mathrm{~kg}$ ). All BMTs were 6/6 HLA matched while $90 \%$ of UCBTs were $1-2$ HLA mismatched. Similar to the study by Laughlin et al. (2004), UCBT recipients received ten-fold less TNCs compared to BMT recipients $\left(0.23 \times 10^{8}\right.$ vs. $2.9 \times 10^{8}$ per $\mathrm{kg}$ of body weight). ANC ( $\left.>500 \mathrm{cells} / \mathrm{mm}^{3}\right)$ engraftment was significantly delayed in UCBT (26 days vs. 19 days). Primary graft failure occurred in 43 BMT patients and 20 UCBT patients while secondary graft failure occurred in four BMT patients and one UCBT patient. UCBT patients were significantly less likely to experience acute II-IV GVHD when compared to BMT patients (26\% vs. $39 \%, p=0.008$ ) while there was no significant difference in chronic GVHD between the two groups (30\% vs. $46 \%, p=0.07)$. A two-year follow-up demonstrated that TRM and DFS were insignificant between the two groups ( $44 \%$ vs. $38 \%, p=0.13$, and $33 \%$ vs. $38 \%, p=0.06$ ).

A single center study was performed in Japan by Takahashi et al. in 2004 comparing 68 UCBTs and 45 BMTs (Takahashi et al., 2004). Median age of UCBT patients was higher than BMT patients while median weight was higher in BMT patients (36 years and $55.1 \mathrm{~kg}$ vs. 26 years and 59.6kg). Out of 68 UCBT patients, $75 \%$ received 4-5/6 matched CBUs. Most of BMT patients received matched BMTs while only six patients received 5/6 HLA matched BMTs. The patients underwent MAC regimens consisting of cyclophosphamide and TBI. UCB grafts contained more than $2.0 \times 10^{7}$ cells per kg and a median of $0.9 \times 10^{5} \mathrm{CD} 34^{+}$progenitor cells per kg. Within 28 days after transplantation, $4 \%$ of UCBT patients died while $8 \%$ experienced primary graft failure. UCBT recipients had a delayed ANC ( $>500$ cells $/ \mathrm{mm}^{3}$ ) engraftment than BMT recipients (22 days vs. 18 days). Platelet $\left(>20000\right.$ cells $/ \mathrm{mm}^{3}$ ) recovery was observed after 40 and 25 days for UCBTs and BMTs, respectively. The overall myeloid engraftment rates on day 42 were $92 \%$ for UCBT and $100 \%$ for BMT. Despite higher HLA mismatches in UCBTs, acute II- IV and III-IV GVHD incidences were lower than BMTs. Among the patients surviving 100 days after transplantation, 78\% of patients receiving UCBTs and $74 \%$ of those receiving BMTs were affected by chronic GVHD. The hazard ratio for one-year TRM incidence was lower in UCBT patients compared to BMT patients (0.32 vs. 1.0, 95\% CI). However, although there is no apparent risk of relapse in the two groups ( $p=0.73$ ), relapse was slightly lower in UCBT recipients (hazard ratio of 0.76 vs. $1.0,95 \% \mathrm{CI}$ ). DFS was significantly better among patients receiving UCBTs than BMT patients ( $74 \%$ vs. $44 \%)$. Deaths of BMT patients were more likely due to GVHD while no correlation between death and GVHD was observed in UCBT patients. TRM and DFS rates were surprisingly better in UCBT patients than in BMT patients compared to other studies (Laughlin et al., 2004; Rocha et al., 2004). A possible explanation for the improved TRM and DFS rates in this study is that it evaluated patients only from a single center. Lower incidences of acute II-IV GVHD may be explained due to lower degree of diversity for HLA and minor histocompatibility antigens among more 
homogenous population in Japan. Moreover, it has been shown that the Japanese population expresses a higher frequency of the gene that induces interleukin-10 production which may also contribute to lower acute II-IV GVHD incidences (Lin et al., 2003).

\subsubsection{Advantages vs. disadvantages}

Based on the UCBT and BMT studies performed one can determine the advantages and disadvantages of both transplant types. Compared to HSCs from BM, HSCs from UCB are able to engraft not only with reduced GVHD, but also with less severe cases of GVHD (Rocha et al., 2004). A possible reason may be due to immune regulators such as Tregs or MSCs, as described earlier, that are mixed in with UCB. In addition, UCB allow for more diverse transplants due to its ability to engraft despite a higher degree of HLA mismatch. BMTs require at least a 5/6 HLA match while UCBTs require at least a 4/6 HLA match (although a 3/6 match has also proved to be functional)(J. N. Barker et al., 2002). This allows for a much higher probability for finding a patient-donor match. A statistical analysis has shown that patients seeking a CBU will be able to find a 4/6 HLA match 99\% of the time (Beatty, Boucher, Mori, \& Milford, 2000; Stevens, Scaradavou, Carrier, Carpenter, \& Rubinstein, 2005). The probability of finding a 5/6 CBU with a sufficient cell dose ( $\left.>2 \times 10^{7} \mathrm{TNC} / \mathrm{kg}\right)$ is $80 \%$ given that at least 170 000 CBUs are available. Moreover, if a patient is identified for an HSC transplant, the process of finding a CBU match is quicker (days-weeks) than identifying a match for a BMT (weeks-months). The average time for identifying a donor of a CBU is 13.5 days while it is 45 days to identify a BM donor (Barker et al., 2002). It is faster to identify a matching CBU because it will be available for transplant as soon as the unit is identified. It takes longer to acquire a BMT because first, a donor must be identified (average of 19 days), and second, a 30-day period necessary to clear the donor (J. N. Barker et al., 2002). Extraction of HSCs from UCB is noninvasive compared to extraction of HSCs from BM. While BMTs require the use of pervasive extraction procedures (aspiration) which will exert some pain to the donor, cord blood permits easy access to stem cells with no pain to the mother or the newborn. Furthermore, extracting HSCs from BM can lead to donor infection.

A disadvantage of UCB is that the patient has both a longer time-to-neutrophil recovery and time-to platelet recovery. Clinical trials have shown that UCB displayed a time-to-neutrophil recovery (neutrophils $>500$ cells $/ \mathrm{mm}^{3}$ ) ranging from 22-27 days as opposed to an average of 18 days for unrelated BMTs (Taghizadeh \& Sherley). Moreover, UCB presented a time-to-platelet (platelets $>20000$ cells $/ \mathrm{mm}^{3}$ ) recovery of 60 days compared to 29 days for BM transplants (Laughlin et al., 2004). Similarly, another clinical trial exhibited a time-to-neutrophil recovery (neutrophils $>500 \mathrm{cells} / \mathrm{mm}^{3}$ ) average of 27 days for HLA mismatched UCB and 19 days for HLA matched BM recipients (Rocha et al., 2004).

The TNC dose transplanted per kg of body weight is directly correlated with the outcomes of the transplantation (Lim et al., 1999; Tung, Parmar, Robinson, De Lima, \& Shpall, 2010). TNC dose is critical in neutrophil recovery and higher $\mathrm{CD} 34^{+}$cell counts, which is associated with higher engraftment rate, TRM, and improved survival (Barker et al., 2005; Tung et al., 2010). Patients receiving UCBTs of cell doses less than $1.8 \times 10^{7} \mathrm{TNCs}$ and $1.7 \times 10^{5} \mathrm{CD} 34^{+}$cells per kilogram of the recipient body weight had inferior engraftment and survival rates (J. E. Wagner et al., 2002). On average, TNCs in UCB are approximately 10 fold lower than BM. These low amounts of $\mathrm{CD}^{+} 4^{+}$cells may provide an explanation for the delayed engraftment of UCBTs (Eapen et al., 2007; Laughlin et al., 2004; Rocha et al., 2004; Takahashi et al., 2007). Laboratory techniques as well as purification procedures are currently being explored to determine the most efficient methods of collecting or culturing CD34 cells.

\section{Double Cord Blood Transplantation}

Due to the limited cell dose available from one CBU, UCBTs are more ideal for younger, lower weight, patients. Even in UCBTs with small children, delays in engraftment and immune reconstitution are observed compared to other stem cell sources (Tung et al., 2010). Additionally, patients with a total body weight of more than $45 \mathrm{~kg}$ who receive only one CBU are associated with decreased neutrophil and platelet recovery and higher rates of engraftment failure (Tung et al., 2010). In order to overcome low cell dose in UCB HSCs, two methods are often employed, DCBT and ex vivo expansion.

In DCBT, two CBUs, each of which has no more than 2/6 HLA mismatches (low resolution typing of HLA-A and $-\mathrm{B}$ or high resolution typing of HLA-DRB1), are infused together to transplant into adults and large children (Barker et al., 2005; Brunstein et al., 2007; Rocha et al., 2010; Wagner, 2009). The two CBUs chosen for transplantation must have at least a 4/6 HLA match between the units themselves and with the patient.

When a CBU is selected for transplantation, the TNC dose is used to determine if a single unit is sufficient for treatment (Figure 4) (Barker et al., 2005; Brunstein, et al., 2007; Wagner, 2009). A minimum TNC dose of $2.5-3 \times 10^{7}$ per kg of body weight is recommended for each of the two closely matched (5/6 or 6/6 matches) UCB 
units (Tung et al., 2010). A greater mismatch between the two CBUs requires a higher TNC count (Tung et al., 2010). Research suggests use of two CBUs if a single HLA-matched unit has TNC dose of $<3.0 \times 10^{7}$ per $\mathrm{kg}$ (Brunstein et al., 2007; Wagner, 2009). However, Barker et al. (Barker et al., 2005) performed DCBTs on patients when the TNC dose of a single unit was less than $3.5 \times 10^{7}$ per $\mathrm{kg}$ in order to increase graft cell dose for patients. Barker et al. (Barker, Scaradavou, \& Stevens, 2010) further suggested that if the CBU is only 4/6 HLA matched, then the cell dose should be as high as $5.0 \times 10^{7}$ per $\mathrm{kg}$.

\subsection{DCBTs using different conditioning regimens}

Various DCBT studies have been performed separately on MAC, NMAC, and RIC (Table 2) (Ballen et al., 2007; Barker et al., 2005; Barker et al., 2009; Brunstein et al., 2007; Cutler et al., 2010; Kanda et al., in press ; Majhail, Brunstein, \& Wagner, 2006; Rodrigues et al., 2009; Verneris et al., 2009; Yoo et al., 2011). The largest MA study performed by Verneris et al. included 93 DCBT patients and 84 single UCBT patients all diagnosed with acute leukemia or transplantation in first or second complete remission (CR1-2) (Verneris et al., 2009). Median age and weight of DCBT patients were 24 years (range 9-57 years) and 69kg, respectively. At least $90 \%$ of DCBT and single cord recipients received two 4-5/6 HLA matched units. The majority of AML and ALL patients were in CR1 or CR2, and a sub-majority who underwent transplantation in CR1 had high risk clinical features. DCBT recipients received a median infused TNC dose of $3.6 \times 10^{7}$ per $\mathrm{kg}$ of body weight while single cord recipients received a median dose of $3.3 \times 10^{7}$ per $\mathrm{kg}$ of body weight. ANC engraftment recovery was similar between the two groups. Grade II-IV acute GVHD occurred more frequently in DCBT patients than single cord patients (48\% vs. $29 \%, p<0.01)$. A similar trend is observed with chronic GVHD $(18 \%$ vs. $10 \%, p=0.06)$. Relapse was significantly lower in CR1-2 DCBT patients than single cord blood transplant patients ( $16 \%$ vs. $31 \% p<0.03$ ). Verneris et al have determined that two risk factors were associated with relapse, (1) disease state and (2) use of two partially matched CBUs. DFS was similar among the two groups after 5 years $(51 \%$ vs. $40 \%, p=0.35)$. A DCBT study by Barker et al. included recipients of a similar age group. They received similar amounts of TNCs, which resulted in analogous ANC engraftment (Barker et al., 2005). Correspondingly, more patients were likely to have acute II-IV GVHD than chronic GVHD (65\% and 23\%). DFS after 10 months was achieved in 57\% of patients. Similar occurrences were observed in other clinical studies (Barker et al., 2009; Kanda et al., in press).

The largest NMA study using two units of UCB was performed by Brunstein et al. and included 93 patients diagnosed with high risk hematologic diseases (Brunstein et al., 2007). Median age and weight of patients were 51 years and $76 \mathrm{~kg}$, respectively. The majority of recipients received two 4-5/6 matched units. Patients received combined median TNC dose of $3.7 \times 10^{7}$ and median CD34+ dose of $1.2 \times 10^{7}$ per $\mathrm{kg}$ of body weight. ANC engraftment recovery was achieved after 12 days. There were fewer cases of chronic (23\%) than acute II-IV GVHD (59\%). Acute GVHD did not associate with HLA matching. A three-year follow up assessed a 38\% DFS and TRM of $26 \%$. Preexisting high-risk clinical features seemed to be the primary predictors of increased TRM as patients lacking these features showed low TRM. Overall survival was not influenced by age but was rather attributable to severe GVHD and preexisting high-risk clinical features. Chimerism of the two UCB units was observed in 81 patients. Chimerism from each CBU decreased over time (43\% at day 21, $9 \%$ at day 100, and 0\% at one year) until one unit predominated. The contribution of donor-derived cells to the predominant unit was 7\% at day 21 and $0 \%$ at day 100. Factors including cell doses and HLA matching were not predictive of the dominating unit. A possible reason that a relationship was not observed might be attributable to the sequential ( $\sim 1$ hour) infusion of the two units. Ballen et al allowed 3.5-4.5 hours between the infusion of the first and second unit, and observed that the first unit infused predominated 76\% of the time (Ballen et al., 2007).

In a previous study performed by Ballen et al., 21 patients were treated by same RIC with fludarabine/melphalan/rabbit antithymocyte globulin but different GVHD prophylaxis consisted of cyclosporine and mycophenolate mofetil. The median age and weight were 49 years and $78 \mathrm{~kg}$ respectively. The median infused TNC dose was $4.0 \times 10^{7}$ and that of $\mathrm{CD}_{3} 4^{+}$was $1.9 \times 10^{5}$ per $\mathrm{kg}$. After transplantation, two patients experienced primary graft failure. Among the remaining patients, the median time to ANC ( $>500 \mathrm{cells} / \mathrm{mm}^{3}$ ) and platelet count $\left(>20000\right.$ cells $\left./ \mathrm{mm}^{3}\right)$ were 20 days and 41 days respectively. Grade II-IV acute GVHD developed in $40 \%$ of the patients. Among 16 patients evaluable, 31\% suffered chronic GVHD. TRM was $14 \%$ at day 100 and $19 \%$ at 6 months. The two year follow up for OS and DFS were $71 \%$ and $55 \%$. Chimerism was evaluated among 17 patients. Both donor units were initially identified in 6 patients. However, after 12 weeks post-transplantation, single unit predominance was observed in 13 patients, double cord chimerism was observed in 1 patient, and host hematopoiesis along with single cord blood was observed in 3 patients. Of all the patients with single unit predominance, the predominant unit infused first $(p=0.049)$ and generally had higher TNC $(p=0.071)$ and $\mathrm{CD}_{4} 4^{+}(p=0.120)$ counts.

Cutler et al. recently performed a study describing their experiences with 32 patients who underwent DCBT. All 
patients received RIC of fludarabine $\left(180 \mathrm{mg} / \mathrm{m}^{2}\right)$, melphalan $\left(100 \mathrm{mg} / \mathrm{m}^{2}\right)$ and rabbit antithymocyte globulin $(6.0 \mathrm{mg} / \mathrm{kg})$ and received sirolimus, which is a potent immunosuppressant that prevents T-cell mediated alloimmunmity and tacrolimus to prevent acute GVHD. The median age and weight of the patients were 53 years and $75.9 \mathrm{~kg}$ respectively. The majority of patients (91\%) received two 4-6/6 units. UCB units engrafted had a minimum required combined cell dose of $3.7 \times 10^{7} \mathrm{TNC} / \mathrm{kg}$ before cryopreservation and each individual unit had $1.5 \times 10^{7} \mathrm{TNC} / \mathrm{kg}$ pre-cryopreservation. The median pre-cryopreserved combined doses of TNC and CD34 ${ }^{+}$ progenitors were $5.16 \times 10^{7}$ and $1.9 \times 10^{5}$ per kg respectively. The two CBUs were administered sequentially 1 and $6 \mathrm{hr}$ apart, with the unit with higher pre-cryopreservation TNC dose being administered first. Patients achieved ANC $\left(>500\right.$ cells $/ \mathrm{mm}^{3}$ ) ranging from 13-70 days (median $=21$ days) and platelet engraftment at 42 days. Grade II-IV acute GVHD developed in three of 32 patients and chronic GVHD developed in four of 32 patients. Non-relapse mortality at 100 days and two years were $12.5 \%$ and $34.4 \%$ respectively. Chimerism was evaluated among 29 patients who survived, to determine the relative contribution to hematopoiesis. At day $100,62 \%$ of the surviving patients showed evidence of single CBU dominance while both units contributed to hematopoiesis in the remaining patients. The first infused unit was observed to be responsible for the majority of hematopoiesis in $61 \%$ of the patients who showed single CBU dominance. Among the patients with single cord predominance at day $100,67 \%$ had only single unit contributing to hematopoiesis while the remaining patients had evidence of single unit early graft rejection or loss. The median time to relapse after transplantation was 12.6 months while DFS and OS at two years were $31.2 \%$ and $53.1 \%$ respectively. Comparing to the study performed by Ballen et al, there was no significant difference between engraftment rates. However, the incidences of acute GVHD were significantly lower $(p=0.035)$. It is speculated that the use of sirolimus and tacrolimus GVHD prophylaxis reduced the GVHD occurrence since both studies used the same RIC and UCB selection algorithm. Similar results were achieved in studies performed by Ballen (2007) and Rodrigues (2009) in which DFS rates were 55\% and $57 \%$, respectively.

In most patients, only one of the two units gave rise to donor hematopoiesis (Ballen et al., 2007; Brunstein et al., 2007; Cutler et al., 2010). However, this strategy has been shown to improve engraftment (Scaradavou et al., 2010). Moreover, a reduced risk of relapse but higher incidence of acute GVHD may be associated with DCBT compared to single UCBT (Rocha et al., 2010; Scaradavou et al., 2010).

\subsubsection{MA Double Cord Blood Transplants vs. MA single UCBT - Clinical}

There is great difficulty in drawing conclusions from data results when there isn't much data to consider. DCBT TNCs were normally greater than $3.5 \times 10^{7}$ which is approximately two fold greater than single UCBTs. ANC engraftment rates were similar between double and single UCBTs that use MA conditioning regimens. The ANC engraftments for DCBT sranged from 23-25 days, which are comparable to results using single UCBTs. Prevalence of acute II-IV GVHD were diverse among studies in both single and DCBTs, however, the rate of acute II-IV GVHD seemed higher in DCBTs. Chronic GVHD rates were also diverse, but overall seemed to be lower in DCBTs. The percentage of DFS following one or two years in DCBTs was ranged from 51-57\%, which appeared to be lower than single UCBTs.

\section{Ex Vivo Expansion}

An alternative method of overcoming low cell dose of UCB is ex vivo expansion of UCB HSCs. Primitive hematopoietic progenitor cells such as $\mathrm{CD} 133^{+}$and $\mathrm{CD} 34^{+}$from UCB are cultured with cytokines, growth factors and other growth promoting compounds in liquid culture (Tung et al., 2010). The growth factors that are cultured with hematopoietic progenitor cells usually include stem cell factor, interleukin -3, -6, granulocyte colony-stimulating factor, thrombopoietin, and Flt-3 Ligand (Tung et al., 2010). Several other techniques have been attempted to further improve expansion by using histone deacetylases to promote HSC self-renewal, glycogen synthase kinase-3 inhibitors to maintain pluripotency of stem cells, or tetraethylenepentamine to stimulate ex vivo expansion of hematopoietic progenitors (Peled, Landau, Prus, Treves, \& Fibach, 2002; Sato, Ozaki, Oh, Meguro, Hatanaka \& Nagai, 2007; Young et al., 2004).

Another technique to expand UCB is to provide a microenvironment for HSCs. This technique will regulate differentiation and proliferation of HSCs and provide cues that direct hematopoiesis (Tung et al., 2010). One potential attempt to accomplish this is by co-culturing HSCs with MSCs. MSCs derived from the Wharton's jelly of an UC provide stromal support for cord blood HSCs (Bakhshi et al., 2008). In the long-term culture-initiating cell assay, UC MSCs were proven to effectively support the growth of $\mathrm{CD}_{3}{ }^{+}$cells from UCB. Other research suggests co-transplanting MSCs with HSCs in UCBTs (Noort et al., 2002). Co-transplantation may promote engraftment of UCB CD34 ${ }^{+}$cells. Mc Niece et al. (Mc Niece, Harrington, Turney, Kellner, \& Shpall, 2004) isolated and cultured mononuclear cells from UCB on MSC layers ex vivo and observed a 10-20 fold increase in 
TNC, a 7-18 fold increase in committed progenitor cells, a 2-5 fold increase in primitive progenitor cells, and a 16-37 fold increase in CD34 ${ }^{+}$cells after 14 days. Based on previous research, co-culturing HSCs with MSCs may prove to be a potentially effective therapeutic application in HSC transplantation.

\section{Blood extraction and processing}

UCB is currently collected for one of two reasons: (i) donation for public use or (ii) storage for self or family members who are suffering from a disease that can be cured by HSC transplantation (Ballen, Barker, Stewart, Greene, \& Lane, 2008). Expecting mothers must meet certain criteria to be eligible to donate UCB of the newborns. The general eligibility guidelines for expectant mothers, according to the National Marrow Donor Program (National Marrow Donor Program, 2010a), are listed below:

(i) Be at least 18 years of age

(ii) Have no history of hepatitis B or C, HIV, medication-dependent diabetes and cancer

(iii) Have no history of organ transplantation

(iv) Have no history of sexually transmitted diseases within the last 12 months

(v) Have not had tattoos, non-sterile piercings or acupuncture done in the previous 12 months

(vi) Have no malaria history within last three years

UCB is collected after delivery either before placental separation from the uterus wall or after placenta delivery (Ballen et al., 2008). Life force Cryobanks, ViaCord and New England Cord Blood Bank have similar procedures of collecting UCB (Life force Cryobanks, 2011; New England Cord Blood Bank, 2011; Via Cord, 2011). The cord of the baby is clamped and cut postnatally. After the UC is rinsed with antiseptic solution, the umbilical vein is punctured with a needle connected to a standard blood collection bag that contains anticoagulant. Blood flows into the bag by gravity, and after flow stops, the bag is detached and stored away for further processing. This simple procedure used by UCB banks corresponds with the UCB collection technique by Adami et al. (Adami et al., 2005). In this method, the UC was double clamped within 30sec after newborn delivery, and blood was collected while placenta was in utero. The anticoagulant used in the collection bag was citrate-phosphate-dextrose. A similar procedure has been done by Elchalal et al., except that the cord was ligated before clamping to avoid tissue crushing. The UC was then cut between the clamp and ligation. Moreover, massaging or "milking" of the cord was performed at the end of blood flow (Elchalal et al., 2000).

It is important to be cautious when collecting UCB to obtain high-quality CBUs for transplantation. The major issues involved with UCB collection include the volume of UCB collected, microbial infection, delay in blood collection, and blood coagulation (Ballen et al., 2008).

\subsection{Cryopreservation}

The storage process for HSCs is termed cryopreservation and is outlined in Figure 5. UCB is first treated with chemicals such as starch or ammonium chloride to reduce plasma and red blood cell (RBC) counts. RBCs typically lyse easily when they are frozen or thawed. Research suggests that these cell lysates may have detrimental effects when the HSCs are used for transplants (Regidor et al., 1999). Chemical treatment additionally helps reduce blood volume, allowing for easier storage and reduction of cellular debris upon thawing. Once RBCs are depleted; a freezing medium containing dimethyl sulfoxide is added. Dimethyl sulfoxide is a cryoprotectant that helps preserve the cells from the sub-zero temperatures used during the cryopreservation process. The HSCs will freeze at a controlled rate of $1^{\circ} \mathrm{C} / 1 \mathrm{~min}$ until $-80^{\circ} \mathrm{C}$. This process is usually carried out overnight. Several studies have indicated that freezing cells at a controlled rate increases cell viability (Perez-Oteyza et al., 1998 (Balintet al., 2006). The HSCs will then be transferred into a liquid nitrogen tank at a temperature of $-196^{\circ} \mathrm{C}$. The nitrogen tank typically consists of numerous compartments that help in the labeling and identification process.

\subsection{Banking}

There are two types of UCB banks: public and private (Table 3). Public banking is the more widely used of the two and stores donated stem cells to the public registry. Access to stem cells is provided on a first-come first-serve basis. The donation is done with the consent of the mother and at no cost to the family. When a patient needs an UCBT, he/she will have up to a $90 \%$ chance of finding a compatible transplant in a public bank (Novello-Garza et al., 2008). The cost of the transplant, which is generally covered by insurance, ranged from $\$ 15000-\$ 25000$.

Private blood banking stores cord blood exclusively for the family of the newborn. Mothers who have had a 
history of a particular disease in their family that may require a stem cell transplant in the future typically choose this type of banking. The cord blood transplant is guaranteed to be $100 \%$ compatible with the child of the mother. However, this percentage decreases drastically to $25 \%$ compatibility with any relative (J. Wagner et al., 1996). Banking privately costs about $\$ 1500$ in down payment and $\$ 150-\$ 200$ annually. When a transplant is needed, the $\mathrm{CBU}$ is released at no cost to the patient.

\section{Conclusion}

DCBT and ex vivo expansion of HSCs have expanded transplantation into all patients, despite of size or ethnicity. The results of these expansion techniques require a better understanding of the biological processes that occur. The spread and rise of HSC transplantation centers promises further research in the field. Such research may reveal better methods for improving overall GVHD and survival rates in patients who receive HSC transplantations. One implication for future research is to compare the different types of conditioning regimens. It seems that MA conditioning regimens in the analyzed DCBT studies resulted in greater than $50 \%$ DFS in all studies. Co-transplantation of HSCs with MSCs has shown to improve patient outcomes but requires additional study (Blanc et al., 2007; in't Anker et al., 2003; Maitraet al., 2004).Further investigation for using UCB to aid in remodeling of the myocardium following an acute myocardial infarction may also be executed. It has been shown that heterogeneous cell populations of bone marrow containing hematopoietic and mesenchymal progenitor cells are able to improve post-infarction remodeling processes (Britten et al., 2003; Lunde et al., 2006; Schächinger et al., 2006) UCB contains similar progenitor cells and thus may have the potential to aid in the restoration of the contractile functions of the myocardium.

\section{References}

Adami, V., Malangone, W., Falasca, E., Marini, L., Risso, A., Crini, S., et al. (2005). A closed system for the clinical banking of umbilical cord blood. Blood Cells, Molecules, and Diseases, 35 (3), 389-397. http://dx.doi.org/10.1016/j.bcmd.2005.07.008

Aggarwal, S. \& Pittenger, M. F. (2005). Human mesenchymal stem cells modulate allogeneic immune cell responses. Blood, 105 (4), 1815-1822. http://dx.doi.org/ 10.1182/blood-2004-04-1559

Anderson, B. E., McNiff, J. M., Matte, C., Athanasiadis, I., Shlomchik, W. D., \& Shlomchik, M. J. (2004). Recipient CD4+ T cells that survive irradiation regulate chronic graft-versus-host disease. Blood, 104 (5), 1565-1573. http://dx.doi.org/10.1182/blood-2004-01-0328

Bacigalupo, A., Ballen, K., Rizzo, D., Giralt, S., Lazarus, H., Ho, V., et al. (2009). Defining the intensity of conditioning regimens: Working definitions. Biology of Blood and Marrow Transplantation, 15 (12), 1628-1633. http://dx.doi.org/10.1016/j.bbmt.2009.07.004

Bakhshi, T., Zabriskie, R. C., Bodie, S., Kidd, S., Ramin, S., Paganessi, L. A., et al. (2008). Mesenchymal stem cells from the wharton's jelly of umbilical cord segments provide stromal support for the maintenance of cord blood hematopoietic stem cells during long-term ex vivo culture. Transfusion, 48 (12), 2638-2644. http://dx.doi.org/10.1111/j.1537-2995.2008.01926.x

Balint, B., Paunovic, D., Vucetic, D., Vojvodic, D., Petakov, M., Trkuljic, M., et al. (2006). Controlled-rate versus uncontrolled-rate freezing as predictors for platelet cryopreservation efficacy. Transfusion, 46 (2), 230-235. http://dx.doi.org/10.1111/j.1537-2995.2006.00706.x

Ballen, K. K., Barker, J. N., Stewart, S. K., Greene, M. F., \& Lane, T. A. (2008). Collection and preservation of cord blood for personal use. Biology of Blood and Marrow Transplantation, 14 (3), 356-363. http://dx.doi.org/10.1016/j.bbmt.2007.11.005

Ballen, K. K., Spitzer, T. R., Yeap, B. Y., McAfee, S., Dey, B. R., Attar, E., et al. (2007). Double unrelated reduced-intensity umbilical cord blood transplantation in adults. Biology of Blood and Marrow Transplantation, 13 (1), 82-89. http://dx.doi.org/10.1016/j.bbmt.2006.08.041

Barker, J. N., Scaradavou, A., \& Stevens, C. E. (2010). Combined effect of total nucleated cell dose and HLA match on transplantation outcome in 1061 cord blood recipients with hematologic malignancies. Blood, 115 (9), 1843-1849. http://dx.doi.org/10.1182/blood-2009-07-231068

Barker, J. N., Abboud, M., Rice, R. D., Hawke, R., Schaible, A., Heller, G., et al. (2009). A "No-wash" albumin-dextran dilution strategy for cord blood unit thaw: High rate of engraftment and a low incidence of serious infusion reactions. Biology of Blood and Marrow Transplantation, 15 (12), 1596-1602. http://dx.doi.org/10.1016/j.bbmt.2009.08.009

Barker, J. N., Weisdorf, D. J., DeFor, T. E., Blazar, B. R., McGlave, P. B., Miller, J. S., et al. (2005). 
Transplantation of 2 partially HLA-matched umbilical cord blood units to enhance engraftment in adults with hematologic malignancy. Blood, 105 (3), 1343-1347. http://dx.doi.org/10.1182/blood-2004-07-2717

Barker, J. N., Krepski, T. P., DeFor, T. E., Davies, S. M., Wagner, J. E., \&Weisdorf, D. J. (2002). Searching for unrelated donor hematopoietic stem cells: Availability and speed of umbilical cord blood versus bone marrow. Biology of Blood and Marrow Transplantation, 8 (5), 257-260. http://dx.doi.org/10.1053/bbmt.2002.v8.pm12064362

Batten, P., Sarathchandra, P., Antoniw, J. W., Tay, S. S., Lowdell, M. W., Taylor, P. M., \& Yacoub, M. H. (2006). Human mesenchymal stem cells induce $\mathrm{T}$ cell anergy anddownregulate $\mathrm{T}$ cell allo-responses via the TH2 pathway: Relevance to tissue engineering human heart valves. Tissue Engineering, 12 (8), 2263-2273. http://dx.doi.org/10.1089/ten.2006.12.2263

Beatty, P. G., Boucher, K. M., Mori, M., \& Milford, E. L. (2000).Probability of finding HLA-mismatched related or unrelated marrow or cord blood donors. Human Immunology, 61 (8), 834-840. http://dx.doi.org/10.1016/S0198-8859(00)00138-5

Bieback, K. \& Kluter, H. (2009). Non-hematopoietic stem and progenitor cells derived from human umbilical cord blood. In N. Bhattacharya, \& P. Stubblefield (Eds.). Frontiers of cord blood science (1st ed., pp. 123-161). London: Springerlink.

Bieback, K., Kern, S., Kluter, H., \& Eichler, H. (2004). Critical parameters for the isolation of mesenchymal stem cells from umbilical cord blood. Stem Cells, 22 (4), 625-634. http://dx.doi.org/10.1634/stemcells.22-4-625

Britten, M. B., Abolmaali, N. D., Assmus, B., Lehmann, R., Honold, J., Schmitt, J., et al. (2003). Infarct remodeling after intracoronary progenitor cell treatment in patients with acute myocardial infarction (TOPCARE-AMI): Mechanistic insights from serial contrast-enhanced magnetic resonance imaging. Circulation, 108 (18). 2212-2218. http://dx.doi.org/10.1161/01.CIR.0000095788.78169.AF

Blanc, K. L., Samuelsson, H., Gustafsson, B., Remberger, M., Sundberg, B., Arvidson, J., et al. (2007).Transplantation of mesenchymal stem cells to enhance engraftment of hematopoietic stem cells; MSCs to enhance engraftment of allogeneic HSCs. Leukemia, 21, 1733-1738. http://dx.doi.org/10.1038/sj.leu.2404777

Broxmeyer, H. E. (May 26, 2010). Cord blood hematopoietic stem cell transplantation. StemBook (1st ed.). The stem cell research community.

Broxmeyer, H. E., Douglas, G. W., Hangoc, G., Cooper, S., Bard, J., English, D., et al. (1989). Human umbilical cord blood as a potential source of transplantable hematopoietic stem/progenitor cells. Proceedings of the National Academy of Sciences of the United States of America, 86 (10), 3828-3832.

Brunstein, C. G., Barker, J. N., Weisdorf, D. J., DeFor, T. E., Miller, J. S., Blazar, B. R., et al. (2007). Umbilical cord blood transplantation after nonmyeloablative conditioning: Impact on transplant outcomes in 110 adults with hematological disease.Blood, 110 (8), 3064-3070. http://dx.doi.org/10.1182/blood-2007-04-067215

Carrier, E. \& Ledingham, G. (2004). 100 questions \& answers about bone marrow and stem cell transplantation (1st ed.). Massachusetts: Jones and Bartlett Publishers, Inc.

Casper, J., Knauf, W., Kiefer, T., Wolff, D., Steiner, B., Hammer, U., et al. (2004). Treosulfan and fludarabine: A new toxicity-reduced conditioning regimen for allogeneic hematopoietic stem cell transplantation. Blood, 103 (2), 725-731. http://dx.doi.org/10.1182/blood-2002-11-3615

Chen, X., Vodanovic-Jankovic, S., Johnson, B., Keller, M., Komorowski, R., \& Drobyski, W. R. (2007). Absence of regulatory T-cell control of TH1 and TH17 cells is responsible for the autoimmune-mediated pathology in chronic graft-versus-host disease. Blood, 110 (10), 3804-3813. http://dx.doi.org/10.1182/blood-2007-05-091074

Chen, Y., Shao, J., Xiang, L., Dong, X., \& Zhang, G. (2008). Mesenchymal stem cells: A promising candidate in regenerative medicine. The International Journal of Biochemistry \& Cell Biology, 40 (5), 815-820. http://dx.doi.org/10.1016/j.biocel.2008.01.007

Cohen, J. L., Trenado, A., Vasey, D., Klatzmann, D., \& Salomon, B. L. (2002). CD4+CD25+ immunoregulatory T cells. The Journal of Experimental Medicine, 196 (3), 401-406. http://dx.doi.org/10.1084/jem.20020090

Cutler, C., Stevenson, K., Kim, H. T., Brown, J., McDonough, S., Herrera, M., et al. (2010). Double umbilical cord blood transplantation with reduced intensity conditioning and sirolimus-based GVHD prophylaxis. Bone Marrow Transplantation. [Epub ahead of print], 1-9. http://dx.doi.org/10.1038/bmt.2010.192

Eapen, M., Rubinstein, P., Zhang, M., Stevens, C., Kurtzberg, J., Scaradavou, A., et al. (2007). Outcomes of transplantation of unrelated donor umbilical cord blood and bone marrow in children with acute leukaemia: A 
comparison study. The Lancet, 369 (9577), 1947-1954. http://dx.doi.org/10.1016/S0140-6736(07)60915-5

Elchalal, U., Fasouliotis, S. J., Shtockheim, D., Brautbar, C., Schenker, J. G., Weinstein, D., et al. (2000). Postpartum umbilical cord blood collection for transplantation: A comparison of three methods. American Journal of Obstetrics and Gynecology, 182 (1), 227-232. http://dx.doi.org/10.1016/S0002-9378(00)70517-5

Fontenot, J. D., Rasmussen, J. P., Williams, L. M., Dooley, J. L., Farr, A. G., \& Rudensky, A. Y. (2005). Regulatory T cell lineage specification by the forkhead transcription factor Foxp3. Immunity, 22 (3), 329-341. http://dx.doi.org/10.1016/j.immuni.2005.01.016

Giralt, S. (2005). Reduced-intensity conditioning regimens for hematologic malignancies: What have we learned over the last 10 years? Hematology, 2005 (1), 384-389. http://dx.doi.org/10.1182/asheducation-2005.1.384

Glennie, S., Soeiro, I., Dyson, P. J., Lam, E. W. F., \& Dazzi, F. (2005). Bone marrow mesenchymal stem cells induce division arrest anergy of activated $\mathrm{T}$ cells. Blood, 105 (7), 2821-2827. http://dx.doi.org/10.1182/blood-2004-09-3696

Gluckman, E., Broxmeyer, H. E., Auerbach, A. D., Friedman, H. S., Douglas, G. W., Devergie, A., et al. (1989). Hematopoietic reconstitution in a patient with fanconi's anemia by means of umbilical-cord blood from an HLA-identical sibling. New England Journal of Medicine, 321 (17), 1174-1178. http://dx.doi.org/10.1056/NEJM198910263211707

Groh, M. E., Maitra, B., Szekely, E., \& Koç, O. N. (2005). Human mesenchymal stem cells require monocyte-mediated activation to suppress alloreactive T cells. Experimental Hematology, 33 (8), 928-934. http://dx.doi.org/10.1016/j.exphem.2005.05.002

Gunsilius, E., Gastl, G., \& Petzer, A. L. (2001). Hematopoietic stem cells.Biomedecine\& Pharmacotherapy, 55 (4), 186-194. http://dx.doi.org/10.1016/S0753-3322(01)00051-8

Higuchi, A., Yang, S., Li, P., Tamai, M., Tagawa, Y., Chang, Y., et al. (2010). Direct ex vivo expansion of hematopoietic stem cells from umbilical cord blood on membranes. Journal of Membrane Science, 351 (1-2), 104-111. http://dx.doi.org/10.1016/j.memsci.2010.01.034

Horwitz, M. E. \& Chao, N. (2010). Non-myeloablative umbilical cord blood transplantation. Best Practice \& Research Clinical Haematology, 23 (2), 231-236. http://dx.doi.org/10.1016/j.beha.2010.06.001

in 't Anker, P. S., Noort, W. A., Kruisselbrink, A. B., Scherjon, S. A., Beekhuizen, W., Willemze, R., et al. (2003). Nonexpanded primary lung and bone marrow-derived mesenchymal cells promote the engraftment of umbilical cord blood-derived CD34+ cells in NOD/SCID mice. Experimental Hematology, 31 (10), 881-889. http://dx.doi.org/10.1016/S0301-472X(03)00202-9

Jeong, J. A., Hong, S. H., Gang, E. J., Ahn, C., Hwang, S. H., \& Yang, I. H. (2005). Differential gene expression profiling of human umbilical cord blood-derived mesenchymal stem cells. Stem Cells, 23 (4), 584-593. http://dx.doi.org/10.1634/stemcells.2004-0304

Kanda, J., Rizzieri, D. A., Gasparetto, C., Long, G. D., Chute, J. P., Sullivan, K. M., et al. Adult dual umbilical cord blood transplantation using myeloablative total body irradiation (1350 cGy) and fludarabine conditioning. Biology of Blood and Marrow Transplantation, In Press, Corrected Proof. http://dx.doi.org/10.1016/j.bbmt.2010.09.009

Kang, X., Zang, W., Bao, L., Li, D., Xu, X., \& Yu, X. (2006). Differentiating characterization of human umbilical cord blood-derived mesenchymal stem cells in vitro. Cell Biology International, 30 (7), 569-575. http://dx.doi.org/10.1016/j.cellbi.2006.02.007

Kern, S., Eichler, H., Stoeve, J., Kluter, H., \&Bieback, K. (2006). Comparative analysis of mesenchymal stem cells from bone marrow, umbilical cord blood, or adipose tissue. Stem Cells, 24 (5), 1294-1301. http://dx.doi.org/10.1634/stemcells.2005-0342

Kestendjieva, S., Kyurkchiev, D., Tsvetkova, G., Mehandjiev, T., Dimitrov, A., Nikolov, A., et al. (2008). Characterization of mesenchymal stem cells isolated from the human umbilical cord. Cell Biology International, 32 (7), 724-732. http://dx.doi.org/10.1016/j.cellbi.2008.02.002

Kiel, M. J., Yilmaz, Ö. H., Iwashita, T., Yilmaz, O. H., Terhorst, C., \& Morrison, S. J. (2005). SLAM family receptors distinguish hematopoietic stem and progenitor cells and reveal endothelial niches for stem cells. Cell, 121 (7), 1109-1121. http://dx.doi.org/10.1016/j.cell.2005.05.026

Kim, Y. \& Broxmeyer, H. E. Immune regulatory cells in umbilical cord blood and their potential roles in transplantation tolerance. Critical Reviews in oncology/hematology, In Press, Corrected Proof. 
http://dx.doi.org/10.1016/j.critrevonc.2010.07.009

Knudtzon, S. (1974). In vitro growth of granulocytic colonies from circulating cells in human cord blood. Blood, 43 (3), 357-361.

Kurt Benirschke \& Peter Kaufmann. (2000). Anatomy and pathology of the umbilical cord and major fetal vessels. Pathology of the human placenta (4th. ed., pp. 335). New York: Springer-Verlag New York, Inc.

Kurtzberg, J., Laughlin, M., Graham, M. L., Smith, C., Olson, J. F., Halperin, E. C., et al. (1996). Placental blood as a source of hematopoietic stem cells for transplantation into unrelated recipients. New England Journal of Medicine, 335 (3), 157-166. http://dx.doi.org/10.1056/NEJM199607183350303

Laporte, J., Gorin, N., Rubinstein, P., Lesage, S., Portnoi, M., Barbu, V., et al. (1996). Cord-blood transplantation from an unrelated donor in an adult with chronic myelogenous leukemia. New England Journal of Medicine, 335 (3), 167-170. http://dx.doi.org/10.1056/NEJM199607183350304

Laughlin, M. J., Eapen, M., Rubinstein, P., Wagner, J. E., Zhang, M., Champlin, R. E., et al. (2004). Outcomes after transplantation of cord blood or bone marrow from unrelated donors in adults with leukemia. New England Journal of Medicine, 351 (22), 2265-2275. http://dx.doi.org/10.1056/NEJMoa041469

Leary, A. \& Ogawa, M. Blast cell colony assay for umbilical cord blood and adult bone marrow progenitors. Blood, 69 (3), 953-956.

LifeforceCryobanks. (2011). The collection process. Retrieved 2/25, 2011. [Online] Available: http://www.lifeforcecryobanks.com/what/collection/

Lim, F. T. H., Beckhoven, J., Brand, A., Kluin-Nelemans, J., Hermans, J. M. H., Willemze, R., et al. (1999). The number of nucleated cells reflects the hematopoietic content of umbilical cord blood for transplantation. Bone Marrow Transplantation, 24 (9), 965.

Lin, M., Storer, B., Martin, P. J., Tseng, L., Gooley, T., Chen, P., et al. (2003). Relation of an interleukin-10 promoter polymorphism to graft-versus-host disease and survival after hematopoietic-cell transplantation. New England Journal of Medicine, 349 (23), 2201-2210. http://dx.doi.org/10.1056/NEJMoa022060

Lunde, K., Solheim, S., Aakhus, S., Arnesen, H., Abdelnoor, M., Egeland, T., et al. (2006). Intracoronary injection of mononuclear bone marrow cells in acute myocardial infarction. New England Journal of Medicine, 355 (12). 1199-1209. http://dx.doi.org/10.1056/NEJMoa055706

Maitra, B., Szekely, E., Gjini, K., Laughlin, M. J., Dennis, J., Haynesworth S. E., et al. (2004). Human mesenchymal stem cells support unrelated donor hematopoietic stem cells and suppress T-cell activation. Bone Marrow Transplantation, 33 (6), 597-604. http://dx.doi.org/10.1038/sj.bmt.1704400

Majhail, N. S., Brunstein, C. G., \& Wagner, J. E. (2006). Double umbilical cord blood transplantation. Current Opinion in Immunology, 18 (5), 571-575. http://dx.doi.org/doi:10.1016/j.coi.2006.07.015

Mayani, H., Alvarado-Moreno, J. A., \& Flores-Guzmán, P. (2003). Biology of human hematopoietic stem and progenitor cells present in circulation. Archives of Medical Research, 34 (6), 476-488. http://dx.doi.org/10.1016/j.arcmed.2003.08.004

McNiece, I., Harrington, J., Turney, J., Kellner, J., \& Shpall, E. J. (2004). Ex vivo expansion of cord blood mononuclear cells on mesenchymal stem cells. Cytotherapy, 6, 311-317. http://dx.doi.org/10.1080/14653240410004871

Mielcarek, M. \& Storb, R. (2003). Non-myeloablative hematopoietic cell transplantation as immunotherapy for hematologic malignancies. Cancer Treatment Reviews, 29 (4), 283-290. http://dx.doi.org/10.1016/S0305-7372(03)00004-5

Morrison, S. J., Hemmati, H. D., Wandycz, A. M., \& Weissman, I. L. (1995). The purification and characterization of fetal liver hematopoietic stem cells. Proceedings of the National Academy of Sciences of the United States of America, 92 (22), 10302-10306. http://dx.doi.org/ 10.1073/pnas.92.22.10302

National Marrow Donor Program (2010a). Learn if you can donate cord blood. Retrieved 12/5, 2010. [Online] Available:

http://www.marrow.org/HELP/Donate_Cord_Blood_Share_Life/How_to_Donate_Cord_Blood/Learn_If_You_C an_Donate/index.html

National Marrow Donor Program (2010b). U.S. NMDP transplant centers. Retrieved 11/20, 2010. [Online] Available: 
http://www.marrow.org/PATIENT/Plan_for_Tx/Choosing_a_TC/US_NMDP_Transplant_Centers/tc_list_by_stat e.pl

Nakamae, H., Kirby, K. A., Sandmaier, B. M., Norasetthada, L., Maloney, D. G., Maris, M. B., et al. (2009). Effect of conditioning regimen intensity on CMV infection in allogeneic hematopoietic cell transplantation. Biology of Blood and Marrow Transplantation, 15 (6), 694-703. http://dx.doi.org/10.1016/j.bbmt.2009.02.009

New England Cord Blood Bank. (2011). Cord blood. Retrieved 2/25, 2011. [Online] Available: http://www.cordbloodbank.com/cord-blood.php

Noort, W. A., Kruisselbrink, A. B., in't Anker, P. S., Kruger, M., van Bezooijen, R. L., de Paus, R. A., et al. (2002). Mesenchymal stem cells promote engraftment of human umbilical cord blood-derived CD34(+) cells in NOD/SCID mice. Experimental Hematology, 30, 870-878. http://dx.doi.org/10.1016/S0301-472X(02)00820-2

Novello-Garza, B., Limon-Flores, A., Guerra-Marquez, A., Luna-Bautista, F., Juan-Shum, L., Montero-Ines, et al. (2008). Establishing a cord blood banking and transplantation program in mexico: A single institution experience. Transfusion, 48, 228-236. http://dx.doi.org/ 10.1111/j.1537-2995.2007.01529.x

Osawa, M., Hanada, K., Hamada, H., \& Nakauchi, H. (1996). Long-term lymphohematopoietic reconstitution by a single CD34-Low/Negative hematopoietic stem cell. Science, 273 (5272), 242-245. http://dx.doi.org/10.1126/science.273.5272.242

Panepucci, R. A., Siufi, J. L., Silva, W. A., Proto-Siquiera, R., Neder, L., \& Orellana, M. (2004). Comparison of gene expression of umbilical cord vein and bone marrow-derived mesenchymal stem cells.Stem Cells, 22 (7), 1263-2278. http://dx.doi.org/ 10.1634/stemcells.2004-0024

Parry, E. W. \& Abramovich, D. R. (1972). The ultrastructure of human umbilical vessel endothelium from early pregnancy to full term. Journal of Anatomy, 111 (1), 29-42.

Pasquini, M. C. \& Wang, Z. (2010). Current use and outcome of hematopoietic stem cell transplantation: CIBMTR summary slides. Retrieved Novemeber 26, 2010. [Online] Available: http://www.cibmtr.org

Peled, T., Landau, E., Prus, E., Treves, A. J., \& Fibach, E. (2002). Cellular copper content modulates differentiation and self-renewal in cultures of cord blood-derived CD34+ cells. British Journal of Haematology, 116 (3), 655-661. http://dx.doi.org/10.1046/j.0007-1048.2001.03316.x

Perez-Oteyza, J., Bornstein, R., Corral, M., Hermosa, V., Alegre, A., Torrabadella, M., et al. (1998). Controlled-rate versus uncontrolled-rate cryopreservation of peripheral blood progenitor cells: A prospective multicenter study. Group for cryobiology and biology of bone marrow transplantation (CBTMO), Spain.Haematologica, 83 (11), 1001-1005.

Regidor, C., Posada, M., Monteagudo, D., Garaulet, C., Somolinos, N., Forés, R., et al. (1999). Umbilical cord blood banking for unrelated transplantation: Evaluation of cell separation and storage methods. Experimental Hematology, 27 (2), 380-385. http://dx.doi.org/10.1016/S0301-472X(98)00016-2

Ringdén, O., Uzunel, M., Rasmusson, I., Remberger, M., Sundberg, B., Lönnies, H., et al. (2006).Mesenchymal stem cells for treatment of therapy-resistant graft-versus-host disease. Transplantation, 81 (10), 1390-1397.

Soiffer, R. J. (2008). Biology of transplantation. In Soiffer, R. J. \& Karp, J. E. (Eds.), Hematopoietic stem cell transplantation (2nd ed., pp. 3). New Jersey: Humana Press.

Rocha, V., Cornish, J., Sievers, E. L., Filipovich, A., Locatelli, F., Peters, C., et al. (2001). Comparison of outcomes of unrelated bone marrow and umbilical cord blood transplants in children with acute leukemia. Blood, 97 (10), 2962-2971. http://dx.doi.org/10.1182/blood.V97.10.2962

Rocha, V., Crotta, A., Ruggeri, A., Purtill, D., Boudjedir, K., Herr, A., et al. (2010). Double cord blood transplantation: Extending the use of unrelated umbilical cord blood cells for patients with hematological diseases. Best Practice \& Research Clinical Haematology, 23 (2), 223-229. http://dx.doi.org/10.1016/j.beha.2010.07.005

Rocha, V., Labopin, M., Sanz, G., Arcese, W., Schwerdtfeger, R., Bosi, A., et al. (2004).Transplants of umbilical-cord blood or bone marrow from unrelated donors in adults with acute leukemia. New England Journal of Medicine, 351 (22), 2276-2285. http://dx.doi.org/10.1056/NEJMoa041469

Scherjon, S. \& Anker, I. E. (2009). In utero stem cell transplantation. In C. H. Rodeck \& M. J. Whittle (Eds.). Fetal medicine: Basic science and clinical practice, 2nd ed., pp. 678-684. New York: Churchill Livingstone Else. 
Rodrigues, C. A., Sanz, G., Brunstein, C. G., Sanz, J., Wagner, J. E., Renaud, M., et al. (2009). Analysis of risk factors for outcomes after unrelated cord blood transplantation in adults with lymphoid malignancies: A study by the eurocord-netcord and lymphoma working party of the european group for blood and marrow transplantation. Journal of Clinical Oncology, 27 (2), 256-263. http://dx.doi.org/10.1200/JCO.2007.15.8865

Romanov, Y. A., Svintsitskaya, V. A., \& Smirnov, V. N. (2003). Searching for alternative sources of postnatal human mesenchymal stem cells: Candidate MSC-like cells from umbilical cord. Stem Cells, 21 (1), 105-110. http://dx.doi.org/10.1634/stemcells.21-1-105

Sakaguchi, S., Yamaguchi, T., Nomura, T., \& Ono, M. (2008). Regulatory T cells and immune tolerance. Cell, 133 (5), 775-787. http://dx.doi.org/10.1016/j.cell.2008.05.009

Sato, K., Ozaki, K., Oh, I., Meguro, A., Hatanaka, K., Nagai, T., et al. (2007). Nitric oxide plays a critical role in suppression of T-cell proliferation by mesenchymal stem cells. Blood, 109 (1), 228-234. http://dx.doi.org/10.1182/blood-2006-02-002246

Sato, N., Meijer, L., Skaltsounis, L., Greengard, P., \& Brivanlou, A. H. (2004). Maintenance of pluripotency in human and mouse embryonic stem cells through activation of Wnt signaling by a pharmacological GSK-3-specific inhibitor. Nature Medicine, 10 (1), 55-63. http://dx.doi.org/10.1038/nm979

Satwani, P., Cooper, N., Rao, K., Veys, P., \& Amrolia, P. (2008). Reduced intensity conditioning and allogeneic stem cell transplantation in childhood malignant and nonmalignant diseases. Bone Marrow Transplantation, 41 (2), 173-182. http://dx.doi.org/10.1038/sj.bmt.1705923

Scaradavou, A., Smith, K. M., Hawke, R., Schaible, A., Abboud, M., Kernan, N. A., et al. (2010). Cord blood units with low CD34+ cell viability have a low probability of engraftment after double unit transplantation. Biology of Blood and Marrow Transplantation, 16 (4), 500-508. http://dx.doi.org/10.1016/j.bbmt.2009.11.013

Schächinger, V., Erbs, S., Elsässer, A., Haberbosch, W., Hambrecht, R., Hölschermann, H., et al. (2006). Intracoronary bone Marrow-Derived progenitor cells in acute myocardial infarction. New England Journal of Medicine, 355 (12), 1210-1221. http://dx.doi.org/10.1056/NEJMoa060186

Spangrude, G., Brooks, D., \& Tumas, D. (1995). Long-term repopulation of irradiated mice with limiting numbers of purified hematopoietic stem cells: In vivo expansion of stem cell phenotype but not function. Blood, 85 (4), 1006-1016.

Stevens, C. E., Scaradavou, A., Carrier, C., Carpenter, C., \& Rubinstein, P. (2005). An empirical analysis of the probability of finding a well matched cord blood unit: Implications for a national cord blood inventory. ASH Annual Meeting Abstracts, 106 (11), 2047.

Taghizadeh, R. R. \& Sherley, J. L. Expanding the therapeutic potentials of umbilical cord blood hematopoietic stem cells. In Cetrulo, C. L., Cetrulo, K. J., \&Cetrulo, C. L. Jr. (Eds.), Perinatal stem cells (1st ed., pp.21-35), John Wiley \& Sons, Inc.

Takahashi, S., Iseki, T., Ooi, J., Tomonari, A., Takasugi, K., Shimohakamada, Y., et al. (2004). Single-institute comparative analysis of unrelated bone marrow transplantation and cord blood transplantation for adult patients with hematologic malignancies. Blood, 104 (12), 3813-3820. http://dx.doi.org/10.1182/blood-2004-03-1001

Takahashi, S., Ooi, J., Tomonari, A., Konuma, T., Tsukada, N., Oiwa-Monna, M., et al. (2007). Comparative single-institute analysis of cord blood transplantation from unrelated donors with bone marrow or peripheral blood stem-cell transplants from related donors in adult patients with hematologic malignancies after $\begin{array}{llllll}\text { myeloablative } & \text { conditioning } & \text { regimen. } & \text { Blood, } & 109 & \text { (3), }\end{array}$ http://dx.doi.org/10.1182/blood-2006-04-020172

Taylor, P. A., Lees, C. J., \& Blazar, B. R. (2002). The infusion of ex vivo activated and expanded CD4+ CD25+ immune regulatory cells inhibits graft-versus-host disease lethality. Blood, 99 (10), 3493-3499. http://dx.doi.org/10.1182/blood.V99.10.3493

Taylor, P. A., Panoskaltsis-Mortari, A., Swedin, J. M., Lucas, P. J., Gress, R. E., Levine, B. L., et al. (2004). L-selectinhi but not the L-selectinlo CD4+25+ T-regulatory cells are potent inhibitors of GVHD and BM graft rejection. Blood, 104 (12), 3804-3812. http://dx.doi.org/10.1182/blood-2004-05-1850

Trenado, A., Charlotte, F., Fisson, S., Yagello, M., Klatzmann, D., Salomon, B. L., et al. (2003).

Recipient-type specific $\mathrm{CD} 4{ }^{+} \mathrm{CD} 25^{+}$regulatory $\mathrm{T}$ cells favor immune reconstitution and control graft-versus-host disease while maintaining graft-versus-leukemia. The Journal of Clinical Investigation, 112 (11), 1688-1696. http://dx.doi.org/10.1172/JCI200317702 
Tung, S. S., Parmar, S., Robinson, S. N., De Lima, M., \& Shpall, E. J. (2010). Ex vivo expansion of umbilical cord blood for transplantation. Best Practice \& Research Clinical Haematology, 23 (2), 245-257. http://dx.doi.org/10.1016/j.beha.2010.06.004

University of Alabama at Birmingham Medicine. 2008. Fetal Circulation. Retrieved 9/12, 2010. [Online] Available: http://www.health.uab.edu/14535/

University of Kansas Medical Center. (2011). Umbilical Cord. Retrieved 9/12, 2010. [Online] Available: http://www.kumc.edu/instruction/medicine/anatomy/histoweb/ct/ct14.htm

Verneris, M. R., Brunstein, C. G., Barker, J., MacMillan, M. L., DeFor, T., McKenna, D. H., et al. (2009). Relapse risk after umbilical cord blood transplantation: Enhanced graft-versus-leukemia effect in recipients of 2 units. Blood, 114 (19), 4293-4299. http://dx.doi.org/10.1182/blood-2009-05-220525

ViaCord. (2011). The cord blood banking process overview. Retrieved 2/25, 2011. [Online] Available: http://www.viacord.com/cord-blood-banking-process.htm

Vriesendorp, H. M. (2003). Aims of conditioning. Experimental Hematology, 31 (10), 844-854. http://dx.doi.org/10.1016/S0301-472X(03)00229-7

Wagers, A. J., Sherwood, R. I., Christensen, J. L., \& Weissman, I. L. (2002). Little evidence for developmental plasticity of adult hematopoietic stem cells. Science, 297 (5590), 2256-2259. http://dx.doi.org/10.1126/science.1074807

Wagner, J. E., Barker, J. N., DeFor, T. E., Baker, K. S., Blazar, B. R., Eide, C., et al. (2002). Transplantation of unrelated donor umbilical cord blood in 102 patients with malignant and nonmalignant diseases: Influence of CD34 cell dose and HLA disparity on treatment-related mortality and survival. Blood, 100 (5), 1611-1618. http://dx.doi.org/10.1182/blood-2002-01-0294

Wagner, J., Rosenthal, J., Sweetman, R., Shu, X., Davies, S., Ramsay, N., et al. (1996). Successful transplantation of HLA-matched and HLA-mismatched umbilical cord blood from unrelated donors: Analysis of engraftment and acute graft-versus-host disease. Blood, 88 (3), 795-802.

Wagner, J. E. (2009). Should double cord blood transplants be the preferred choice when a sibling donor is unavailable? Best Practice \& Research Clinical Haematology, 22 (4), 551-555. http://dx.doi.org/10.1016/j.beha.2009.09.003

Wang, J., Wang, L., Wu, Y., Xiang, Y., Xie, C., Jia, B., et al. (2004). Mesenchymal stem/progenitor cells in human umbilical cord blood as support for ex vivo expansion of CD34+ hematopoietic stem cells and for chondrogenic differentiation.Haematologica, 89 (7), 837-844.

Yoo, K. H., Lee, S. H., Sung, K. W., Koo, H. H., Chung, N. G., Cho, B., et al. (2011). Current status of pediatric umbilical cord blood transplantation in Korea: A multicenter retrospective analysis of 236 cases. American Journal of Hematology, 86 (1), 12-17. http://dx.doi.org/10.1002/ajh.21886.

Young, J. C., Wu, S., Hansteen, G., Du, C., Sambucetti, L., Remiszewski, S., et al. (2004). Inhibitors of histone deacetylases promote hematopoietic stem cell self-renewal. Cytotherapy, 6 (4), 328-336. http://dx.doi.org/10.1080/14653240410004899. 
Table 1. Clinical studies comparing unrelated myeloablative single UCBT vs. 6/6 HLA matched BMT in adults

\begin{tabular}{|c|c|c|c|c|c|c|c|c|c|c|}
\hline \multirow[b]{2}{*}{ Study } & \multirow[b]{2}{*}{$\frac{\mathrm{N}-\mathrm{UCB}}{\mathrm{N}-\mathrm{BM}}$} & \multirow[b]{2}{*}{$\begin{array}{l}\text { Median } \\
\text { age } \\
\text { (years) }\end{array}$} & \multirow[b]{2}{*}{ Diagnosis } & \multirow[b]{2}{*}{$\begin{array}{l}\text { Median } \\
\text { infused } \\
\mathrm{TNCx} \\
10^{8} / \mathrm{kg}\end{array}$} & \multicolumn{3}{|c|}{ Engaftment } & \multicolumn{2}{|c|}{ GVHD (\%) } & \multirow[b]{2}{*}{$\begin{array}{c}\text { DFS }(\%) \\
\text { (follow } \\
\text { up in } \\
\text { months) }\end{array}$} \\
\hline & & & & & $\begin{array}{l}\text { ANC } \\
\text { (Day) }\end{array}$ & $\begin{array}{c}\text { Platelets } \\
\text { (Day) }\end{array}$ & $\begin{array}{c}\text { Primaly } \\
\text { failure } \\
(\%)\end{array}$ & $\begin{array}{c}\text { Acute II- } \\
\text { IV }\end{array}$ & Chronic & \\
\hline \multirow{2}{*}{$\begin{array}{l}\text { Rochall } \\
\text { (2004) }\end{array}$} & 98 & 24.5 & \multirow[t]{2}{*}{ AML, ALL } & 0.23 & 26 & $\mathrm{~N} / \mathrm{S}$ & 20 & 26 & 30 & $33(24)$ \\
\hline & 584 & 32 & & 2.9 & 19 & $\mathrm{~N} / \mathrm{S}$ & 7 & 39 & 46 & $38(24)$ \\
\hline \multirow{2}{*}{$\begin{array}{l}\text { Laughim }^{*} \\
(2004)\end{array}$} & 150 & $\mathrm{~N} / \mathrm{S}$ & \multirow{2}{*}{$\begin{array}{c}\text { AML, ALL, CML, } \\
\text { MDS }\end{array}$} & 0.22 & 27 & 60 & 30 & 41 & 51 & $23(36)$ \\
\hline & 367 & $\mathrm{~N} / \mathrm{S}$ & & 2.4 & 18 & 29 & $\mathrm{~N} / \mathrm{S}$ & 48 & 35 & $33(36)$ \\
\hline \multirow{2}{*}{$\begin{array}{c}\text { Takahashit } \\
(2004)\end{array}$} & 68 & 36 & \multirow{2}{*}{$\begin{array}{c}\text { AML, ALL, CML, } \\
\text { MDS, NHL }\end{array}$} & 0.25 & 22 & 40 & 8 & 50 & 78 & $74(24)$ \\
\hline & 39 & 26 & & $\mathrm{~N} / \mathrm{S}$ & 18 & 25 & 0 & 75 & 74 & $44(24)$ \\
\hline
\end{tabular}

Abbreviations: $\mathrm{ALL}=$ acute lymphocytic leukemia, $\mathrm{AML}=$ acute myeloid leukemia, $\mathrm{CML}=$ chronic myelogenous leukemia, $\mathrm{NHL}=$ non-Hodgkin's lymphoma, MDS = myelodysplastic syndrome, $T N C=$ total nucleated cell, $\mathrm{ANC}=$ absolute neutrophil count, $\mathrm{GVHD}=$ grat versus host disease, $\mathrm{DFS}=$ disease free survival $N / S=$ not stated

IF For UCBTs, 6 patients received $6 / 6$ HLA-matched units, 85 patients received $4.5 / 6 \mathrm{HLA}$-matched units, and 4 patients received $3 / 6 \mathrm{HLA}$-matched units. * All UCBT patients received 4-5/6 HLA-matched units.

₹ BMT outcomes also include 6 patients who received 5/6 HLA-matched units. For UCBTs, 51 patients received 4-5/6 and 17 received 2-3/6 HLA-matched units.

Table 2. Clinical results of DCBTs using MA/NMA/ or RIC conditioning regimens in adults

\begin{tabular}{|c|c|c|c|c|c|c|c|c|c|c|c|}
\hline \multirow[b]{2}{*}{ Study } & \multirow[b]{2}{*}{$\begin{array}{c}\mathrm{N}- \\
\text { DCBT }\end{array}$} & \multirow[b]{2}{*}{$\begin{array}{l}\text { Median } \\
\text { age(years) }\end{array}$} & \multirow[b]{2}{*}{ Diagnosis } & \multirow[b]{2}{*}{$\begin{array}{l}\text { Conditioning } \\
\text { regimen }\end{array}$} & \multirow[b]{2}{*}{$\begin{array}{l}\text { Median } \\
\text { infused } \\
\text { TNC } x \\
10^{7} / \mathrm{kg}\end{array}$} & \multicolumn{3}{|c|}{ Engraftment } & \multicolumn{2}{|c|}{ GVHD (㣙) } & \multirow[b]{2}{*}{$\begin{array}{c}\text { DFS (Yio) } \\
\text { (follow } \\
\text { ч in } \\
\text { months) }\end{array}$} \\
\hline & & & & & & $\begin{array}{l}\text { ANC } \\
\text { (Day) }\end{array}$ & $\begin{array}{l}\text { Platelets } \\
\text { (Day) }\end{array}$ & $\begin{array}{l}\text { Primary } \\
\text { failure } \\
\text { (Yol) }\end{array}$ & $\begin{array}{l}\text { Acute II- } \\
\text { IV }\end{array}$ & Chronic & \\
\hline $\begin{array}{l}\text { Barker } \\
(2005)\end{array}$ & 23 & 24 & ALL, AML, CML & $\overline{M A}$ & 3.5 & 23 & NS & 0 & 65 & 23 & $57(10)$ \\
\hline $\begin{array}{l}\text { Cutler } \\
\text { (2010) }\end{array}$ & 32 & 53 & $\begin{array}{c}\text { ALL, AML, CML, } \\
\text { NHL, HD, MDS, } \\
\text { CLL. MD }\end{array}$ & RIC & $5.16^{*}$ & 21 & 42 & 0 & 9 & 13 & $31.2(24)$ \\
\hline $\begin{array}{l}\text { Ballen } \\
(2007)\end{array}$ & 21 & 49 & $\begin{array}{l}\text { ALL, AML, CLL, } \\
\text { MDS, NHL, HD, }\end{array}$ & $\mathrm{RIC}$ & 4.0 & 20 & 41 & 10 & 40 & 26 & $55(24)$ \\
\hline $\begin{array}{l}\text { Kanda } \\
(2010)\end{array}$ & 27 & 33 & $\begin{array}{l}\text { ALL, AML, CML, } \\
\text { MDS, NHL, HD }\end{array}$ & MA & 3.8 & 24 & $\mathrm{NS}$ & 12 & 37 & 32 & $52(24)$ \\
\hline $\begin{array}{c}\text { Bunstein } \\
(2007)\end{array}$ & 93 & 51 & $\begin{array}{l}\text { High nisk } \\
\text { hematologic disease }\end{array}$ & NMA & 3.7 & 12 & $\mathrm{NS}$ & 6 & 59 & 23 & $38(36)$ \\
\hline $\begin{array}{l}\text { Majhail } \\
(2006)\end{array}$ & 9 & 28 & $\mathrm{HL}$ & $\mathrm{RIC}$ & 3.8 & 10 & $\mathrm{NSS}$ & 0 & $6 ?$ & 11 & $25(17)$ \\
\hline \multirow{2}{*}{$\begin{array}{l}\text { Barker } \\
(2009)\end{array}$} & 35 & \multirow[t]{2}{*}{42} & \multirow{2}{*}{$\begin{array}{l}\text { Acute leukerisis } \\
\text { NHL, HD, MDS }\end{array}$} & $\mathrm{MA}$ & \multirow[t]{2}{*}{4.46} & 25 & 50 & 6 & \multirow[t]{2}{*}{44} & \multirow[t]{2}{*}{26} & \multirow[t]{2}{*}{$56(12)$} \\
\hline & 19 & & & $\mathrm{NMA}$ & & 10 & 38 & 5 & & & \\
\hline $\begin{array}{l}\text { Rodrigues } \\
(0009)\end{array}$ & 26 & 41 & $\mathrm{NHL}, \mathrm{HL}, \mathrm{CLL}$ & RIC & 3.02 & 17 & NSS & $\mathrm{N} / \mathrm{S}$ & 32 & 19 & $57(18)$ \\
\hline $\begin{array}{l}Y_{00^{2}} \\
(2010)\end{array}$ & 64 & 10.3 & $\begin{array}{c}\text { ALLUABL, AML, } \\
\text { MDSIJMML, SAA, } \\
\text { CML }\end{array}$ & RIC & 4.37 & 19 & 46 & NSS & 41 & 39 & $36.9(60)$ \\
\hline $\begin{array}{l}\text { Wemeris } \\
(2009)\end{array}$ & 93 & 24 & $\begin{array}{l}\text { ALL, AML, High- } \\
\text { risk CR1 }\end{array}$ & $\mathrm{MA}$ & 36 & 25 & $\mathrm{~N} / \mathrm{S}$ & NSS & 48 & 18 & $51(60)$ \\
\hline \multicolumn{12}{|c|}{ 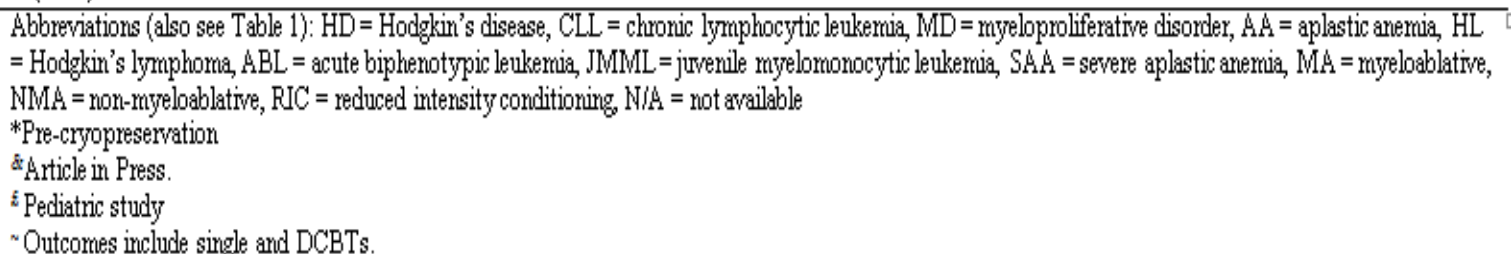 } \\
\hline
\end{tabular}


Table 3. Comparison between public vs. private UCB banking

\begin{tabular}{|lll|}
\hline Categories & Public Bank & Private Bank \\
\hline Purpose of storage & Donate stem cells to public & Keep stem cells for ownchildren \\
\hline Compatibility & $\begin{array}{l}\text { Percentage of finding a match } \\
\text { for a transplant is up to } 90 \%\end{array}$ & $\begin{array}{l}\text { Assures } 100 \% \text { match for } \\
\text { transplantation }\end{array}$ \\
\hline $\begin{array}{l}\text { Probability that you will need } \\
\text { a stem cell transplant }\end{array}$ & N/A & $\begin{array}{l}\text { Probability to use your own } \\
\text { UCB is } 0.0005 \%-0.04 \%\end{array}$ \\
\hline Costs to store & Generally covered by insurance & $\begin{array}{l}\text { Must pay } \$ 1000-2000 \text { to begin } \\
\text { barking and } \$ 100-\$ 200 \\
\text { annually }\end{array}$ \\
\hline $\begin{array}{l}\text { Costs to retrieve stem cells } \\
\text { from the bank }\end{array}$ & Generally covered by insurance & $\begin{array}{l}\text { Does not cost money for } \\
\text { retrieval }\end{array}$ \\
\hline
\end{tabular}

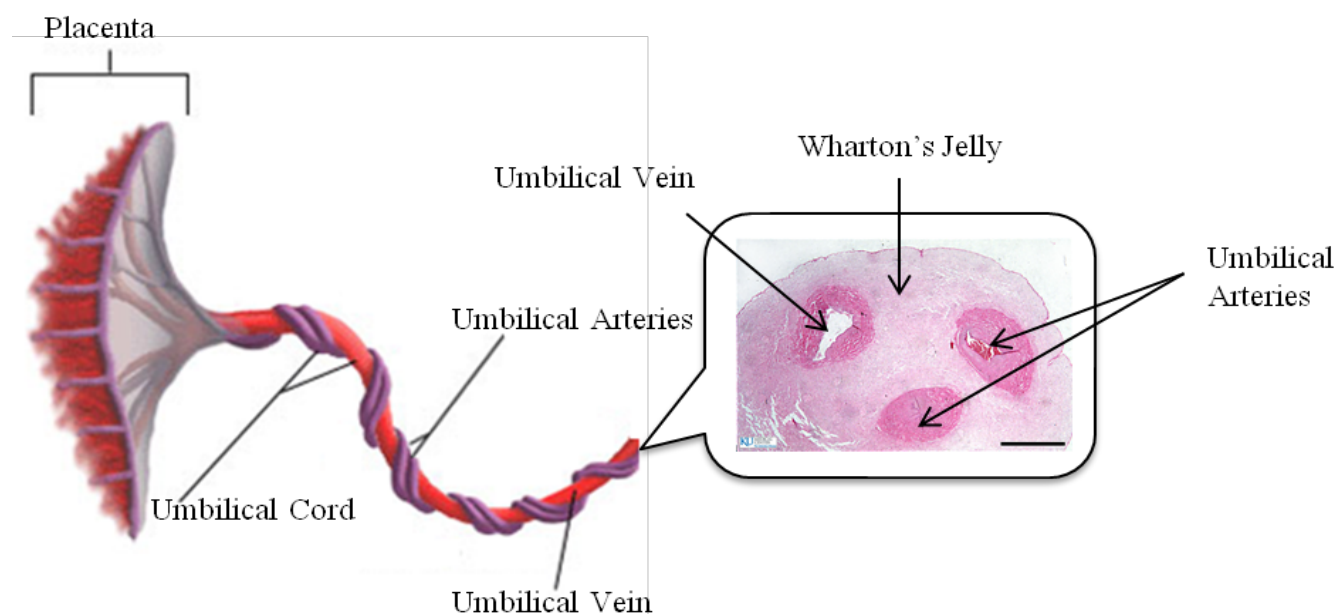

Umbilical Vein

Oxygen-rich blood

Oxygen-poor blood

Mixed blood

Figure 1. The anatomy of the umbilical cord (Courtesy of University of Alabama at Birmingham Medicine, 2008 and University of Kansas Medical Center, 2011)

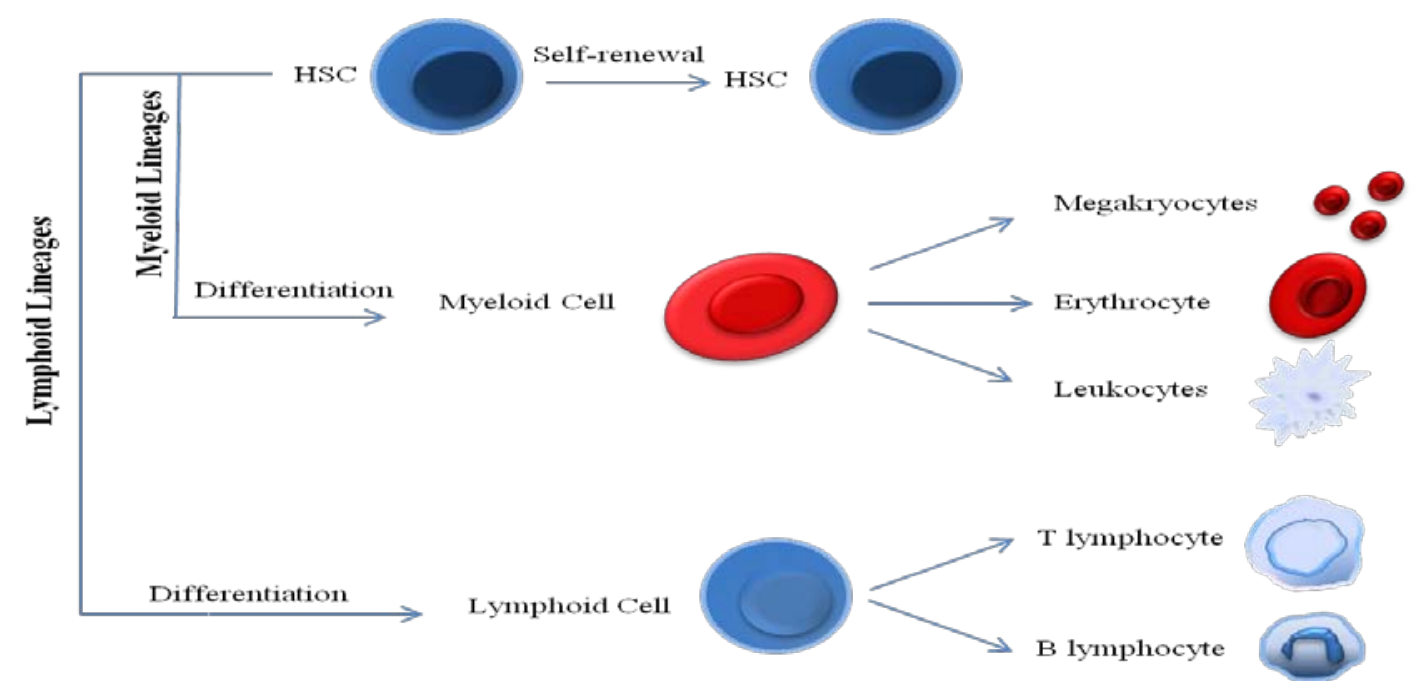

Figure 2. Differentiation pattern of HSCs 


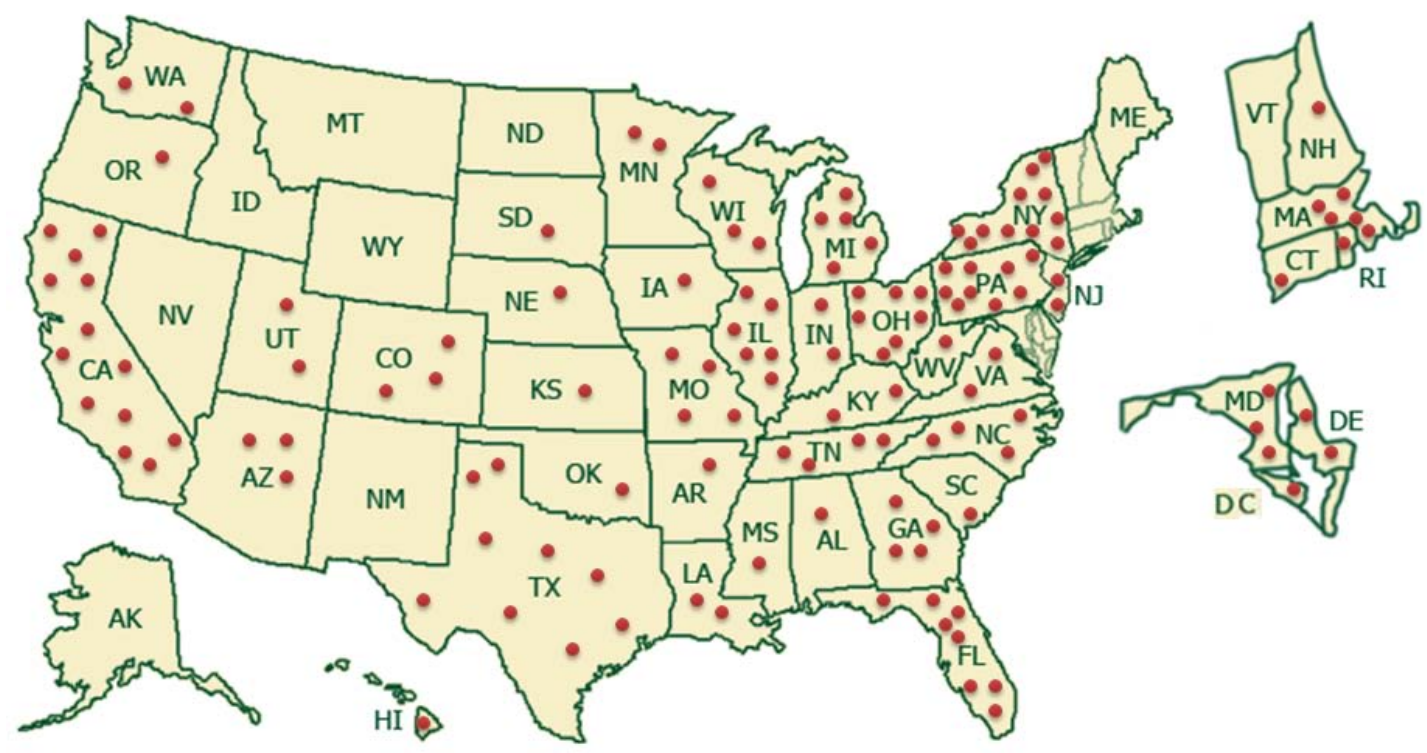

- One transplant center in the National Marrow Donor Program Network (The spots are not indicative of exact location within each state)

Figure 3. Locations of HSC transplantation centers in the United States (National Marrow Donor Program, 2010b)

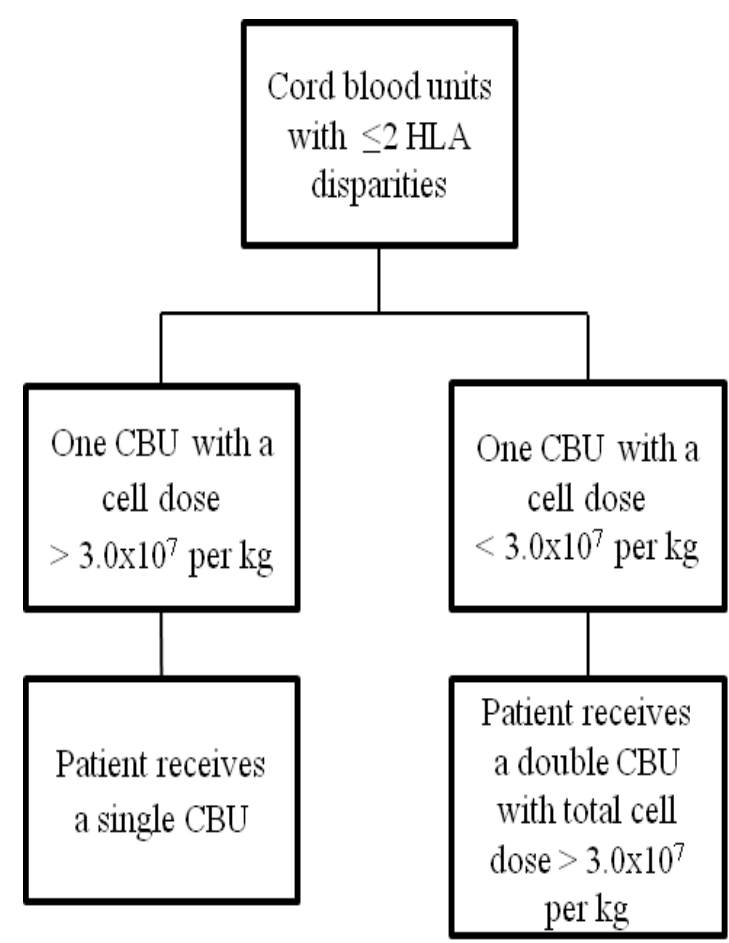

Figure 4. The common algorithm used for UCB selection (Adapted from Wagner, 2009)
Hydroxyethyl starch or ammonium chloride is

used to deplete RBCs

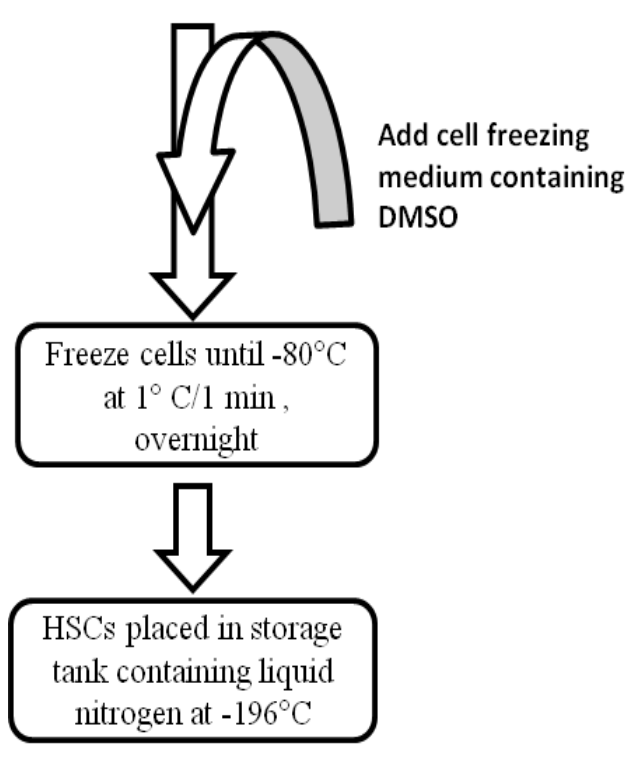

Figure 5. The common cryopreservation process of UCB 